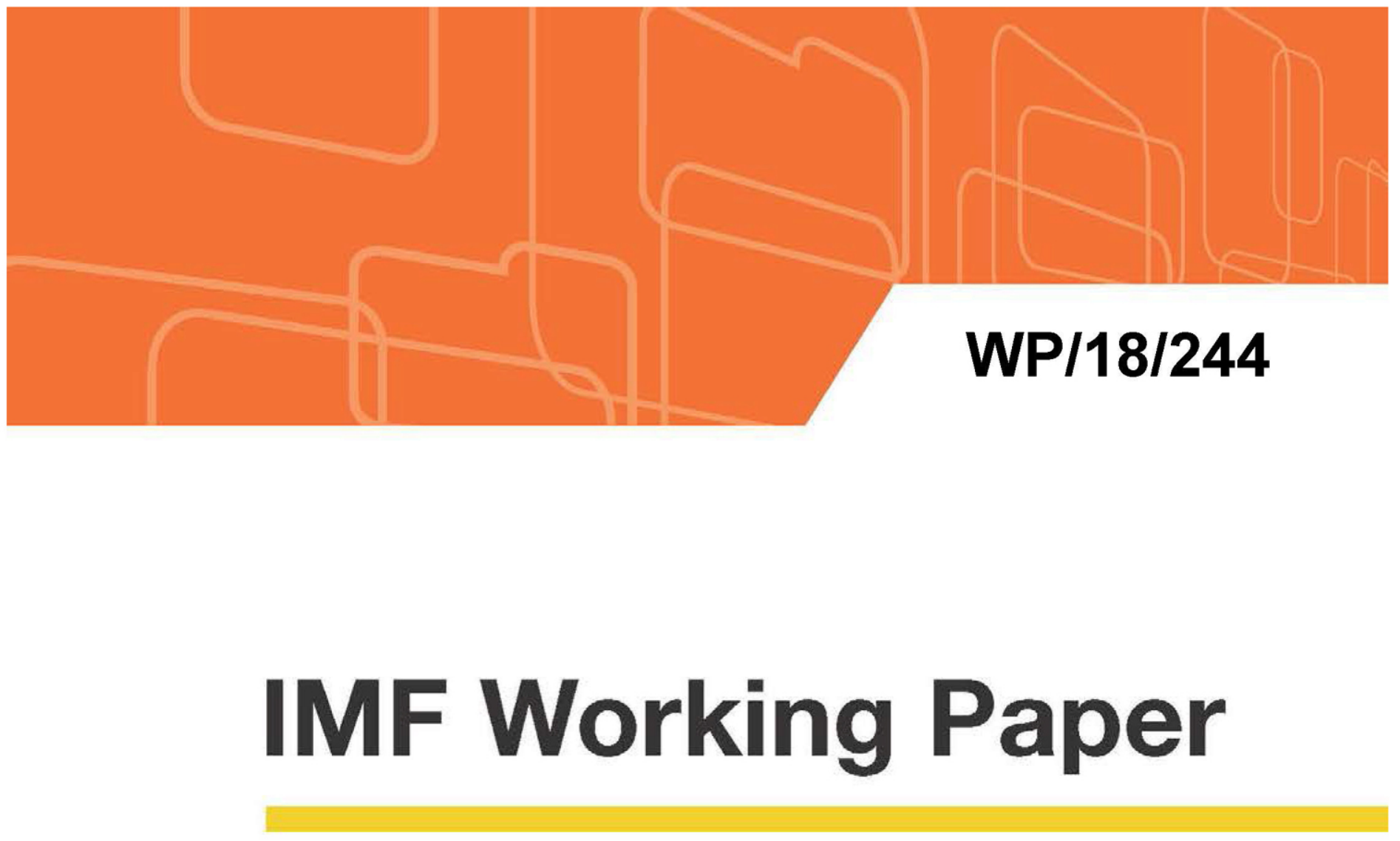

\title{
China's Monetary Policy Communication: Frameworks, Impact, and Recommendations
}

by Michael McMahon, Alfred Schipke, and Xiang Li

IMF Working Papers describe research in progress by the author(s) and are published to elicit comments and to encourage debate. The views expressed in IMF Working Papers are those of the author(s) and do not necessarily represent the views of the IMF, its Executive Board, or IMF management. 


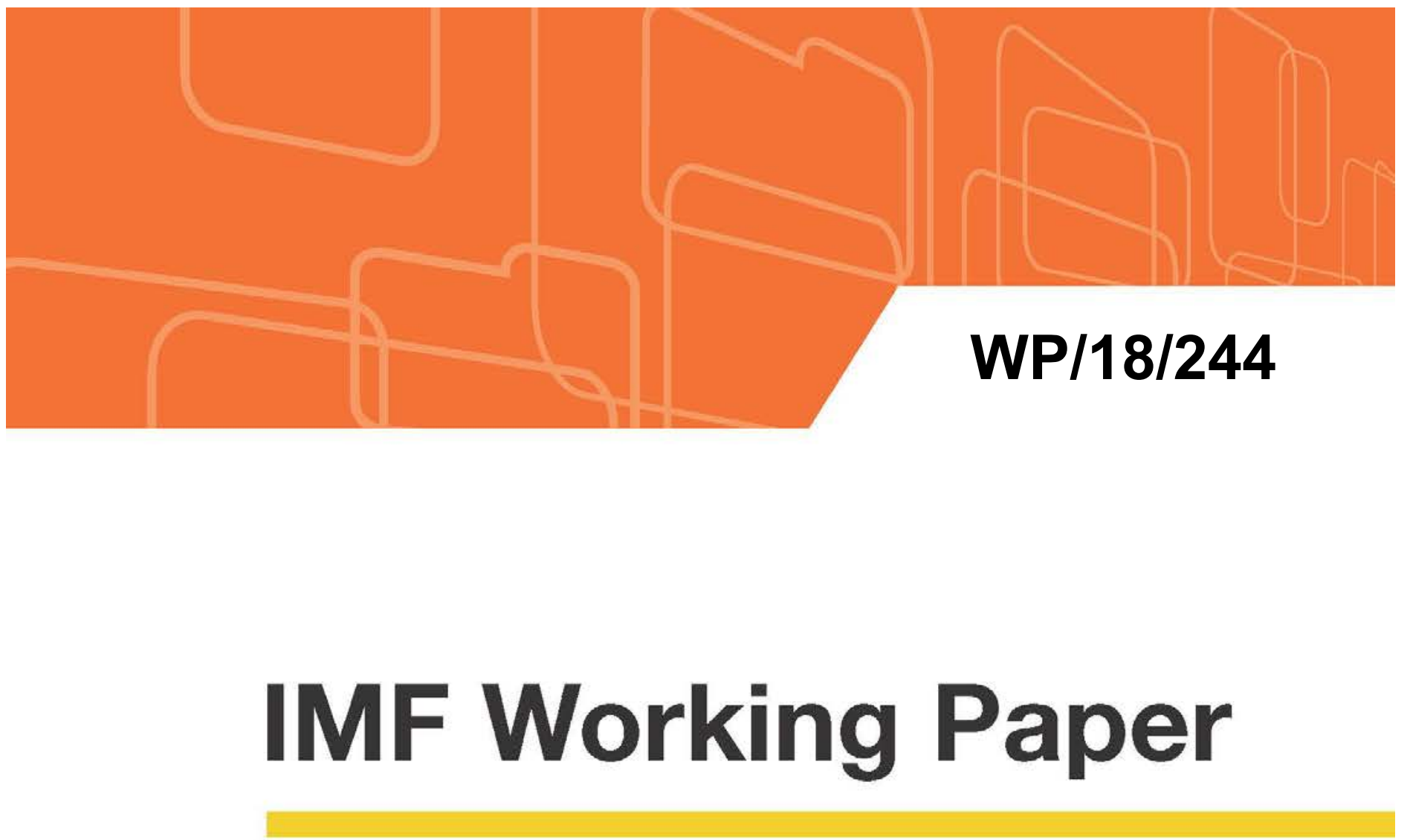

\section{China's Monetary Policy Communication: Frameworks, Impact, and Recommendations}

by Michael McMahon, Alfred Schipke, and Xiang Li

IMF Working Papers describe research in progress by the author(s) and are published to elicit comments and to encourage debate. The views expressed in IMF Working Papers are those of the author(s) and do not necessarily represent the views of the IMF, its Executive Board, or IMF management.

$$
\text { I N T ER N A T I O N A L M O NETAR Y FU N D }
$$




\title{
IMF Working Paper
}

Asia and Pacific Department

\section{China's Monetary Policy Communication: Frameworks, Impact, and Recommendations}

\section{Prepared by Michael McMahon, Alfred Schipke, and Xiang Li ${ }^{1}$}

Authorized for distribution by Alfred Schipke

November 2018

\section{IMF Working Papers describe research in progress by the author(s) and are published to elicit comments and to encourage debate. The views expressed in IMF Working Papers are those of the author(s) and do not necessarily represent the views of the IMF, its Executive Board, or IMF management.}

\begin{abstract}
Financial markets are eager for any signal of monetary policy from the People's Bank of China (PBC). The importance of effective monetary policy communication will only increase as China continues to liberalize its financial system and open its economy. This paper discusses the country's unique instituitional setup and empirically analyzes the impact on financial markets of the PBC's main communication channels, including a novel communication channel. The results suggest that there has been signifcant progress but that PBC communication is still evolving toward the level of other major economies. The paper recommends medium-term policy reforms and reforms that can be adopted quickly.
\end{abstract}

JEL Classification Numbers: E58; E52; E48.

Keywords: Monetary Policy, People's Bank of China, Communication, Central Bank, Financial Markets, Monetary Policy Transmission

Author's E-Mail Address: michael.mcmahon@economics.ox.ac.uk; aschipke@imf.org; xli@iwh-halle.de

\footnotetext{
${ }^{1}$ The authors thank participants at the 2018 Joint People's Bank of China-IMF conference on China's Growing Bond Market in a Global Context for helpful comments and feedback. We also thank Anil Ari, Thomas Harjes, Ma Jun, Nan Li, Stephen Mulema, Rafael Portillo, Filiz Unsal, Ping Wang, Ting Yan, and People’s Bank of China staff for very helpful comments and suggestions.
} 


\section{INTRODUCTION}

This year, 2018, marks 40 years since China initiated "reform and opening up", during which time the country became a growth miracle and the world's second largest economy. As reforms continue, including financial and external sector liberalization, monetary policy will draw increasing attention. Changes to monetary policy, by affecting economic choices, help the domestic economy grow and stabilize and, increasingly, have global implications. Market participants, including international investors, are eager for any signals of monetary policy from People's Bank of China (PBC) communication.

Central banks increasingly use communication as a key lever of monetary policy. Gone are the days of "never explain, never excuse", as put by the Governor of the Bank of England, Montagu Norman (1920-44). ${ }^{2}$ Today, central banks, especially in countries with developed financial systems, regularly communicate. This includes low-frequency communication about their policy frameworks and objectives, as well as higher-frequency communication of views on current macroeconomic conditions, forecasts related to output and inflation, as well as the rationale for policy decisions. ${ }^{3}$ Since the global financial crisis, the implementation of unconventional monetary policies and greater focus on financial sector stability has made communication even more important, especially as it relates to forward guidance.

Compared to other public institutions, central banks are often at the forefront of communication. The PBC is no different and over the past years has strengthened its communication and is keenly aware of the heightened global interest in information about the country's monetary policy. The increase in the number of press conferences and speeches has coincided with sharp stock market adjustments, changes to the exchange rate framework, interest rate liberalization, ${ }^{4}$ and greater financial market volatility in 2015/16. However, communication has not yet become as potent a policy tool as in many advanced economies (such as the U.S. Federal Reserve or the Bank of England) and some important emerging markets.

\footnotetext{
${ }^{2}$ See Bernanke (2007).

${ }^{3}$ On principles and practices of inflation-forecast targeting in advanced economies see Adrian, Tobias; Douglas Laxton, and Maurice Obstfeld (2018).

${ }^{4}$ On May 11, 2015, the PBC expanded the upper limit of the deposit rate floating range from 1.3 times to 1.5 times the benchmark rate; on August 26, the central bank completely liberalized the upper limit of deposit rates with fixed terms longer than one year; and, on October 24, it cancelled the deposit interest rate upper limit of commercial banks and rural cooperative financial institutions. On August 11, 2015, the PBC announced that the CNY/USD rate should refer to the closing rate of the previous day. On December 11 that year, the CFETS CNY index was first released to reinforce the reference to the basket of currencies. Since February 2016, the $\mathrm{CNY/USD}$ fixing rate mechanism consisting of the closing rate and the currency basket was gradually formed and mechanism transparency was increased.
} 
In many respects, China is at a communication's crossroads, driven both by domestic and, increasingly, external factors. Financial and external sector liberalization and greater reliance on price and interest-rate-based allocation of resources, likewise, make communication all the more important. Given the country's global footprint and increasing financial sector linkages, including through different bond and equity connect schemes, this is also true for the international community. As the country moves toward a more flexible exchange rate in conjunction with a monetary policy framework that relies more on shortterm interest rates, better communication will become paramount to improving the effectiveness of monetary policy, reducing excessive volatility, and fostering financial sector stability.

The paper is structured as follows. Section II discusses China's unique institutional setup and Section III provides background about the PBC's main communication channels. Section IV reviews the relevant literature and Section V empirically analyzes the impact of the PBC's communication on financial markets. Section VI recommends policy actions to increase monetary policy effectiveness and to reduce volatility, and Section VII concludes.

\section{China’s UniQue InSTITUTIONAL SETUP}

Compared to other central banks in advanced economies or emerging markets with modern policy frameworks, China's central bank communication is more constrained. This is due to its unique institutional arrangements. In particular, China has multiple and overlapping objectives across institutions. The key constraints are:

- First, the PBC does not have full decision-making power over money supply targets and interest rate policy, and has only limited operational independence at the monetary policy instrument level. Thus, the central bank is constrained in the information and forward guidance that it can convey. At the same time, the PBC drafts and executes monetary policy and has some operational independence, such as in setting short-term interest rates through open market operations, short-term liquidity operations, or rates on standing- and medium-term lending facilities. However, key decisions need to be approved by the State Council (China's equivalent to a government cabinet). ${ }^{5}$ Approval is needed, for example, for changes in the benchmark interest rate, reserve requirements, and the setting of annual monetary aggregates. ${ }^{6}$ For these key policy instruments, the PBC usually proposes policy plans when key economic indicators such as GDP growth and inflation deviate from the targets set at the beginning of each year by the State Council; the State Council then reviews the plans and makes the final decision (Huang, Ge, and Wang 2018). The State Council also regularly approves the wording of the monetary policy stance (Box 1 explains terminology).

\footnotetext{
${ }^{5}$ See Article 2 of the General Rules in the People's Bank of China Law.

${ }^{6}$ See Article 5 of the General Rules in the People's Bank of China Law.
} 
- Second, monetary policy decisions are the result of consensus-building among various stakeholders. State Council members have a broad range of economic and financial sector objectives, and requests for monetary policy changes can be submitted to the State Council not only by the PBC but also by other ministries or agencies. From the central bank's perspective, therefore, both the outcome and the timing of important monetary policy decisions are uncertain, limiting the $\mathrm{PBC}$ from providing forward guidance. As the implementing agency, the $\mathrm{PBC}$ publishes all monetary policy decisions. Also, important PBC personnel and budget decisions go beyond PBC's remit. The PBC governor is nominated by the premier of the State Council, approved by the National People's Congress (or its standing committee when the congress is not in session), and finally appointed and dismissed by the country's President. ${ }^{7}$ The PBC budget, in turn, is part of the central government's budget and supervised by the financial department of the State Council.

- Third, China's monetary policy has numerous objectives. According to Law of the People's Republic of China on the People's Bank of China, "the objective of the monetary policy shall be to maintain stability of the value of the currency and thereby promote economic growth". The PBC is not an inflation-targeting central bank and its objectives in fact go beyond price stability. As the previous PBC governor stated, "the annual objectives of the PBC mandated by the Chinese government have been maintaining price stability, boosting economic growth, promoting employment, and broadly maintaining balance of payments" (Zhou 2016). In addition, the 2017 PBC Work Conference called for monetary policy to balance among economic growth, economic reform, economic structure, household welfare, and financial stability. These multiple objectives often involve trade-offs and reduce transparency. ${ }^{8}$

As China's monetary policy framework is increasingly moving from using quantitative targets to a more price-based framework, effective central bank communication is becoming even more important. As summarized in Huang Ge, and Wang (2018), the PBC's intermediate targets are threefold: quantity-based money supply and bank credit, as well as priced-based market interest rates. Successive waves of interest rate liberalization, which started with money market rates and culminated with the formal elimination of the ceiling on bank deposit rates in 2015, have facilitated the transition toward a modern pricebased monetary policy framework. While the process is not complete, the government in 2018 reiterated its commitment to deepen reforms to make both interest rates and the exchange rate more market based (Li 2018).

\footnotetext{
${ }^{7}$ Deputy governors are appointed and dismissed by China's premier.

${ }^{8}$ On transparency, see Dincer and Eichengreen (2014).
} 
The emphasis on quantitative targets has declined. Since 1994, China has had quantitative monetary targets. However, reflecting financial innovation and a rapidly changing financial system structure, its intermediate quantitative monetary target, M2, is correlated less and less with inflation and growth (Ma 2017). In addition, the M2 outturn has deviated from the target over the past couple of years (Figure 1). As a further indication that emphasis on quantitative targets has declined, the 2018 government Annual Work Report did not specify a specific target/projection for the monetary aggregate (M2), or credit aggregates (such as total social financing). Compared to previous Annual Work Reports, this was an important step forward. Instead, the language was more vague: "Our prudent monetary policy will remain neutral, with easing or tightening as appropriate. We need to make sure that the value of M2 money supply, credit, and aggregate financing ensue a reasonable, stable level of liquidity" (Li 2018).

Figure 1. Monetary Aggregate M2 Growth (Percent)

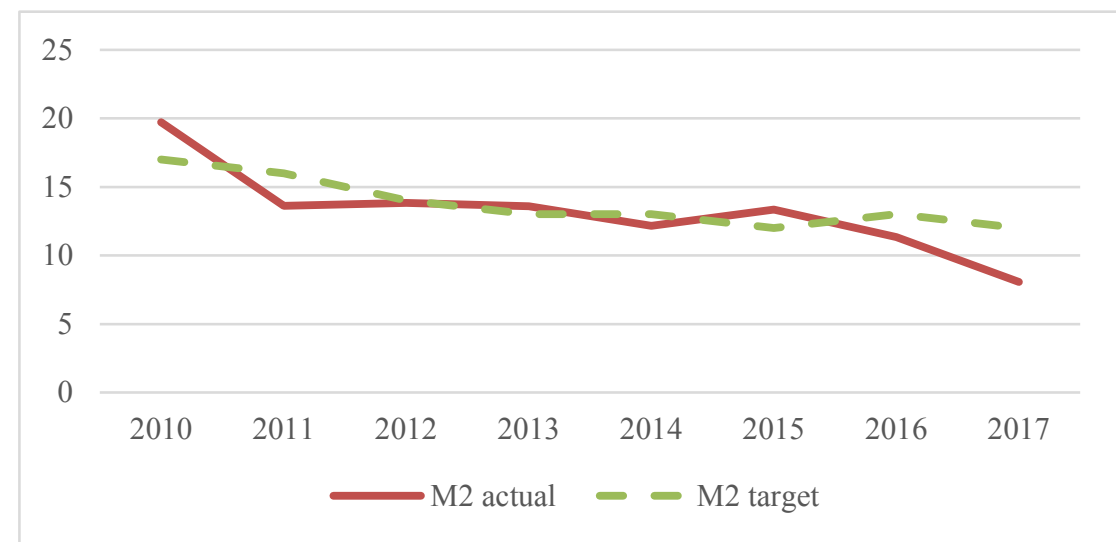

Source: Report on the Work of the Government (2010, 2011, 2012, 2013, 2014, 2015 , 2016, 2017); CEIC.

Interest rate liberalization and other reforms have allowed the $\mathrm{PBC}$ to improve its policy framework. Focus is increasing on short-term money market rates, that is, the 7-day interbank pledged repo rate (DR007). ${ }^{9}$ In the 2016, third-quarter Monetary Policy Executive Report, the PBC stated that "DR007 moves around the open market operation 7-day reverse repo rate. The DR007 can better reflect the liquidity condition in the banking system and has an active role to cultivate the market base rate". Although the PBC has not confirmed DR007 as the policy interest rate yet, it is closely watched by the market. The central bank uses open market operations (OMOs) and the corresponding 7-day OMO repo/reverse repo rate to signal policy changes. For example, from the end of 2015 until mid-2018, the PBC changed OMO rates on seven occasions, of which three coincided with increases in the U.S. Federal Fund's rate. Combined with interest rates for standing lending facilities and remunerated required/excess reserves, the monetary policy framework effectively provides a corridor, that is, an upper and lower bound (Figures 2 and 3).

\footnotetext{
${ }^{9}$ Compared to another 7-day repo rate, which covers nonfinancial institutions (R007), DR007 is the weighted average of participating banks.
} 
Figure 2. Interest Rate Corridor

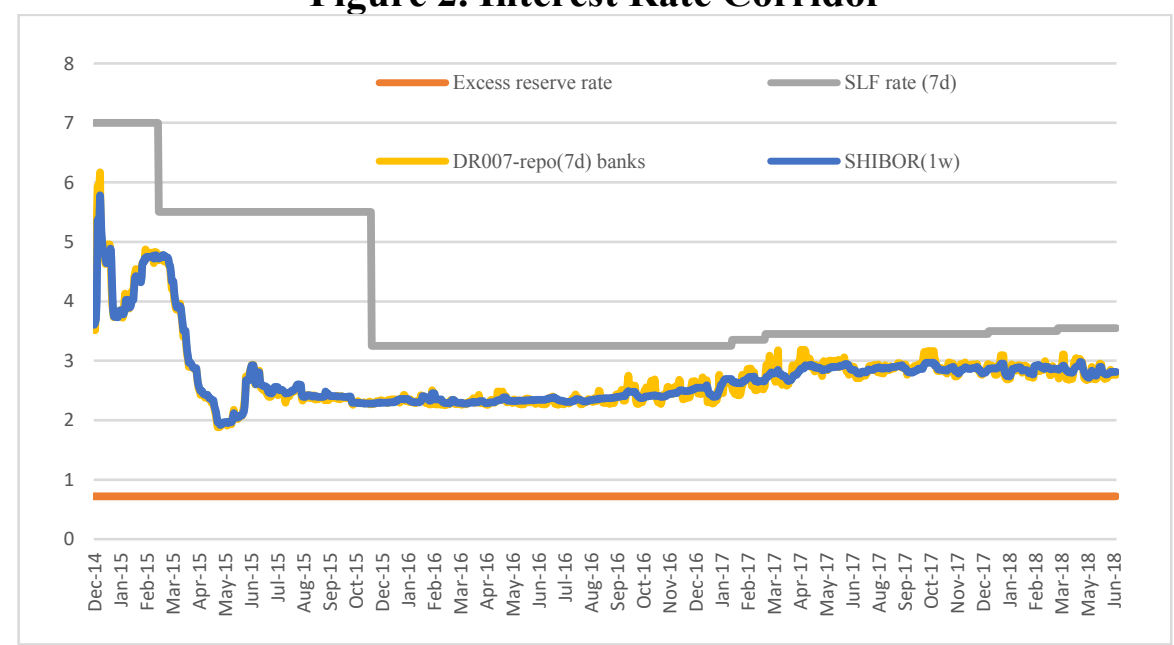

Figure 3. PBC Policy and Target Rate

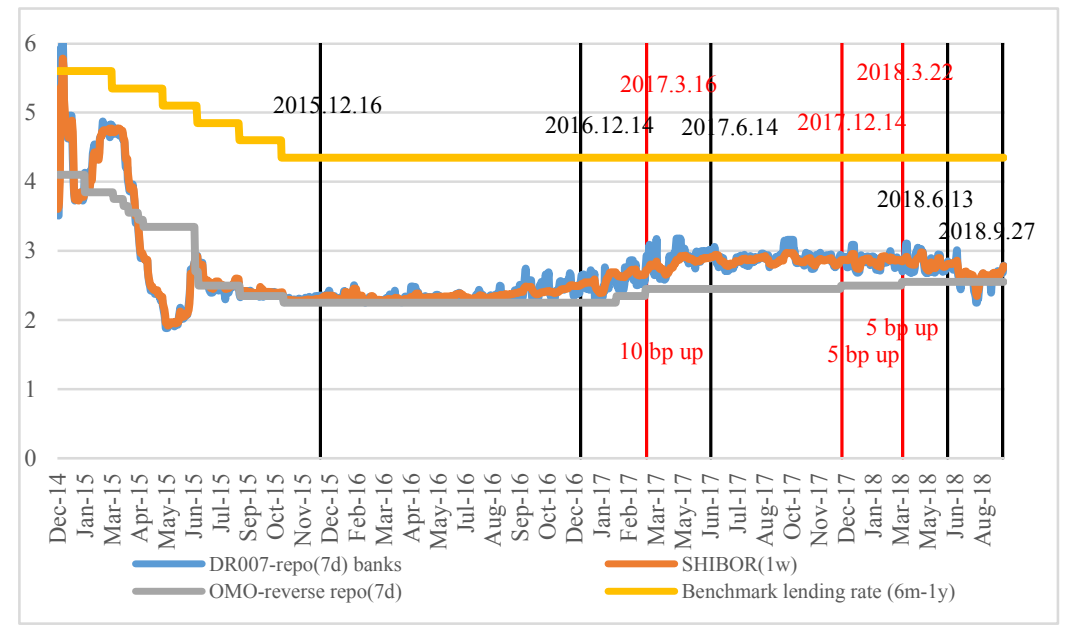

Source: CEIC and WIND.

Note: $b p=$ basis points; vertical black/red bars show recent changes in the U.S. Federal

Funds Rate; those in red reflect changes in PBC's OMO rates.

China's monetary policy framework remains in transition and is currently a hybrid. On the one hand, despite formal interest rate liberalization, banks are still guided by corresponding deposit and lending benchmark rates; changes to these rates go beyond the authority of the PBC and require State Council consent. On the other hand, other policy rates, such as medium-term lending and the pledged supplementary facilities, as well as the use of instruments such as changes in required reserves, undermine transparency and complicate communication (Figures 4, 5 and Table 1).

In April 2018, the PBC indicated its intention to move toward a unified interest rate framework. "In some aspects, the interest rates are 'running on two tracks', that is, there are benchmark interest rates for deposits and loans, while the money market rates are fully liberalized. We have eased restrictions on deposit and loan rates, and commercial banks have been offering deposit and loan rates higher or lower than the benchmark interest rate based 
on their operating conditions. As a matter of fact, the best tactic is for us to gradually unify the two tracks of interest rates, and we are doing just that in the market-based reforms" (PBC 2018a).

Table 1. People's Bank of China Policy and Asset Rates

\begin{tabular}{|c|c|c|}
\hline & Meaning & Tenor \\
\hline \multicolumn{3}{|l|}{ Policy Tools } \\
\hline Benchmark interest rate & $\begin{array}{l}\text { People's Bank of China (PBC) sets the benchmark interest rate as reference } \\
\text { rates for deposits and lending. It is the official policy rate. Unchanged since } \\
\text { October } 2015 \text {. }\end{array}$ & $\begin{array}{l}\text { Less than } 6 \text { months, } 6 \text { months }-1 \text { year, } \\
1-3 \text { years, } 3-5 \text { years, greater than } 5 \\
\text { years }\end{array}$ \\
\hline $\begin{array}{l}\text { Open market operations } \\
\text { (OMO) repo and reverse } \\
\text { repo }\end{array}$ & $\begin{array}{l}\text { Short-term collateralized loans/borrowing. Direct impact on interbank liquidity } \\
\text { conditions. Currently, the } 7 \text {-day reverse repo is used more frequently in } \\
\text { practice, combined with the occasional use of the } 14 \text {-day, } 28 \text {-day and } 63 \text {-day } \\
\text { reverse repo; since } 2013 \text {, the } 91 \text {-day and } 182 \text {-day repo are not used anymore; } \\
21 \text {-day repo is rarely used. }\end{array}$ & $7 / 14 / 21 / 28 / 63 / 91 / 182$ day \\
\hline OMO PBC bill yield & $\begin{array}{l}\text { Money supply changes through issuing central bank bills. Not in use since } \\
\text { November } 2013 \text {. }\end{array}$ & 3-month, 6-month, 1-year, 3-year \\
\hline $\begin{array}{l}\text { Medium-term lending } \\
\text { facility }\end{array}$ & $\begin{array}{l}\text { An instrument to provide the medium-term base money to commercial or } \\
\text { policy banks that meet the requirements of macro-prudential management. } \\
\text { Aims to adjust medium-term funding cost of financial institutions and then the } \\
\text { funding cost of real economy. Created in September } 2014 \text {. }\end{array}$ & 3-month, 6-month, 1-year \\
\hline Standing lending facility & $\begin{array}{l}\text { A liquidity supply channel of the PBC, to meet the temporary liquidity demand } \\
\text { of commercial banks and rural cooperative financial institutions. Seen as the } \\
\text { upper bound of the interest corridor. Created in early } 2013 \text {. }\end{array}$ & Overnight, 7-day, 1-month, \\
\hline $\begin{array}{l}\text { Pledged supplemental } \\
\text { lending }\end{array}$ & $\begin{array}{l}\text { Long-term and large amounts of financing to support the key areas and weak } \\
\text { links of the national economy. Created in April } 2014 .\end{array}$ & Long term \\
\hline $\begin{array}{l}\text { Short-term liquidity } \\
\text { operations }\end{array}$ & $\begin{array}{l}\text { Used when there is a temporary fluctuation in the liquidity of the banking } \\
\text { system, to stabilized market expectation and prevent financial risk. Created in } \\
\text { January } 2013 \text {. }\end{array}$ & Very short term \\
\hline Required reserve ratio & $\begin{array}{l}\text { Share of deposits that banks are required to hold at the PBC. Required reserve } \\
\text { ratio changes can have long-term and large liquidity implications }\end{array}$ & \\
\hline Excessive reserve rate & Rate on excess reserves. Seen as the lower bound of interest rate corridor. & \\
\hline \multicolumn{3}{|l|}{ Money Market Rate } \\
\hline Shibor & $\begin{array}{l}\text { The reference rate based on the interest rates at which banks offer to } \\
\text { lend unsecured funds to other banks in the Shanghai wholesale money market. }\end{array}$ & $\begin{array}{l}\text { Overnight, 1-week, 2-week, 1-month, } \\
\text { 3-month, 6-month, 9-month, 1-year }\end{array}$ \\
\hline R007 & $\begin{array}{l}\text { The weighted average 7-day repurchase rate for the whole market organization, } \\
\text { including all pledged repurchase transactions in the interbank market, and does } \\
\text { not limit trading institutions and underlying assets. }\end{array}$ & 7-day \\
\hline DR007 & $\begin{array}{l}\text { The weighted average 7-day repurchase rate in which deposit institution uses } \\
\text { interest rate bonds as pledge in the interbank market. }\end{array}$ & 7-day \\
\hline FR007 & $\begin{array}{l}\text { Interbank fixing 7-day repo rate, a benchmark rate based on repo trading rate } \\
\text { for interbank market. }\end{array}$ & 7-day \\
\hline CD rate & $\begin{array}{l}\text { Rate of certificate of deposit issued by depository financial institutions in the } \\
\text { interbank market. }\end{array}$ & \\
\hline \multicolumn{3}{|l|}{ Bond Market Rate } \\
\hline $\begin{array}{l}\text { Short-term commercial } \\
\text { paper }\end{array}$ & $\begin{array}{l}\text { Unsecured, short-term debt instrument issued by non-financial corporations in } \\
\text { the interbank bond market, typically for the financing of accounts receivable, } \\
\text { inventories and meeting short-term liabilities. }\end{array}$ & 1-month, 3-month, 6-month and 1-year \\
\hline Medium-term notes & $\begin{array}{l}\text { Debt financing instruments issued by non-financial corporations in the } \\
\text { interbank bond market. }\end{array}$ & $\begin{array}{l}\text { 1-month, 3-month, 6-month, 1-year and } \\
\text { 5-year }\end{array}$ \\
\hline Treasury bond yield & Bonds issued by the government to raise fiscal funds. & $\begin{array}{l}\text { 3-month, 6-month, 1-year, 3-year, 5- } \\
\text { year, 7-year, 10-year and 30-year }\end{array}$ \\
\hline \multicolumn{3}{|l|}{ Equity market rate } \\
\hline $\begin{array}{l}\text { Shanghai Stock Exchange } \\
\text { composite index return }\end{array}$ & $\begin{array}{l}\text { The daily return of the exchange's composite index, a stock market index of all } \\
\text { stocks that are traded at the Shanghai Stock Exchange. }\end{array}$ & \\
\hline
\end{tabular}

Source: People's Bank of China. 
Figure 4. PBC's Hybrid Monetary Policy Framework (Percent, right scale RMB billion)

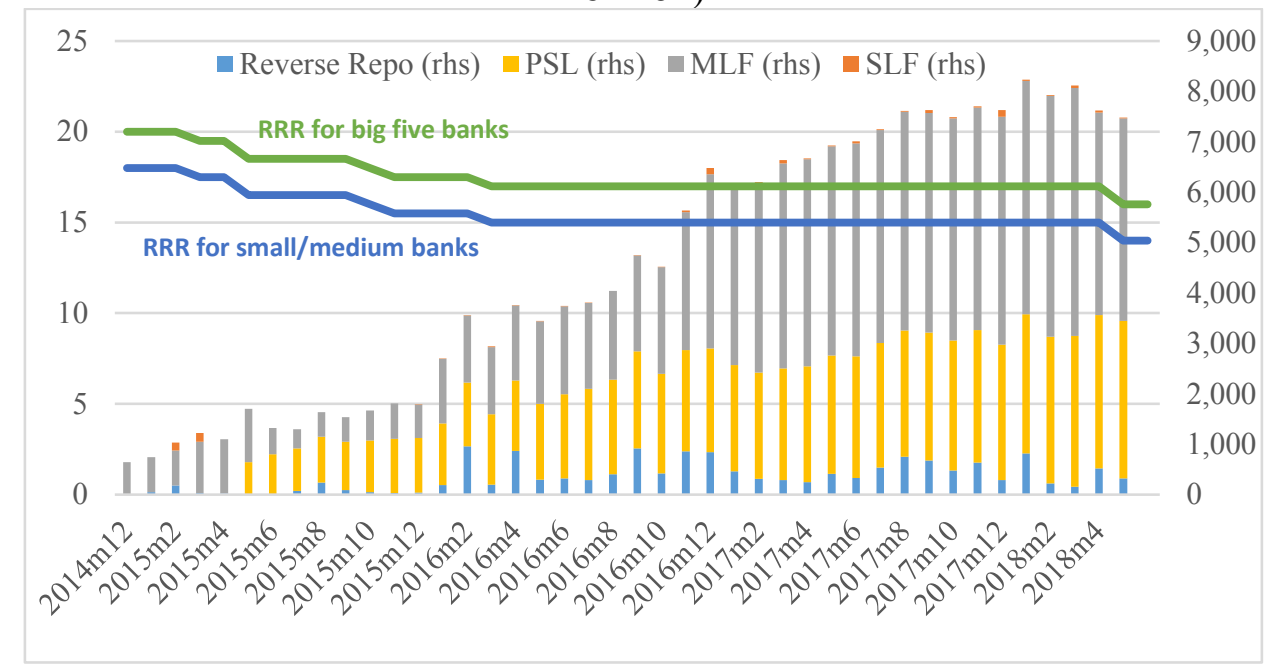

Source: CEIC.

Note: $P S L=$ Pledged Supplementary Lending; $M L F=$ Medium-term Lending Facility; SLF = Standing Lending Facility.

Figure 5. Widening of Interbank-Conventional Deposit Rate
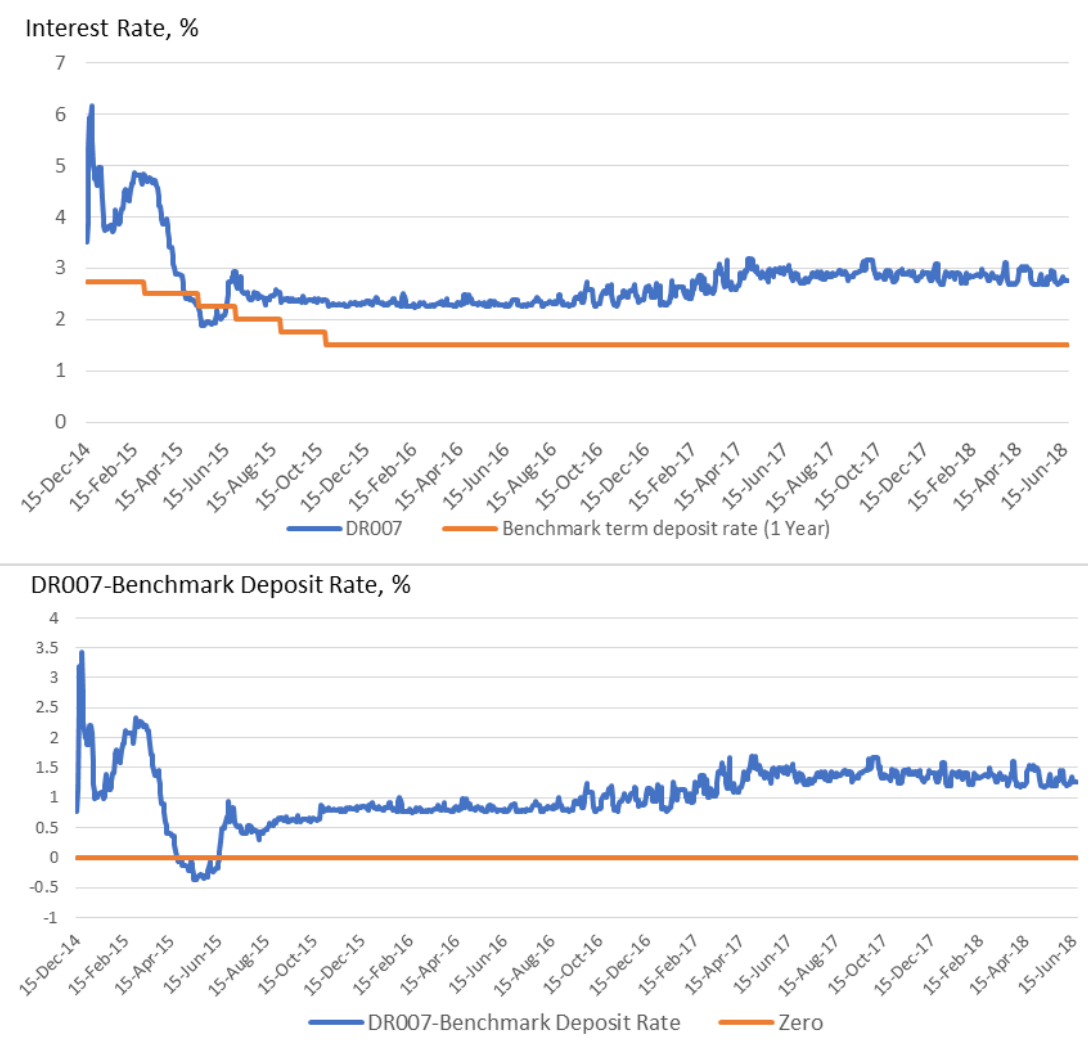

Source: CEIC and WIND 


\section{Evolving Communications Channels}

PBC communication, though still evolving, takes place primarily through four main channels (Box 1 reviews key terms to describe China's monetary policy and use of window guidance):

- Monetary Policy Executive Report (MPER). First issued in 2001, the PBC now releases its MPER quarterly. It covers most recent monetary policy decisions; an analysis of output, prices, and money supply developments; information about important sectors; and assessment of prospects for China's macroeconomic development. Generally, report coverage is more backward looking, but increasingly it provides useful technical and operational information - often within boxes - and, even more recently, some forward looking information.

- Press release on monetary policy committee meetings. The first monetary policy committee meeting was in 1997 and the meeting now takes place at the end of each quarter. Since 2009, the PBC has published press releases one or two days following the meeting. The actual meeting dates, however, are not announced ahead of time and are only posted on the PBC's website following the meeting.

- Speeches and press conferences. Oral communication comprises public speeches by the governor and deputy governors, as well as press conferences. ${ }^{10}$ Public officials regularly give speeches at public conferences or international central bank governor summits. While the contents center around the topics of the conference and cover the PBC's policy stance, sometimes speakers talk about future developments in a specific area. Press conferences are usually scheduled after policy announcements to further explain the rationale for decisions.

- Open market operation notices. To better explain the rationale of OMOs, daily notices have been standard since January 2016. ${ }^{11}$ Increasingly, these notices provide contextual information by adding phrases such as "given ample liquidity, the $\mathrm{PBC}$ has intervened to keep liquidity stable." 12

The PBC is committed to providing more timely information. In 2018, the PBC reiterated that it is committed to "continuously improve the central bank's credibility and transparency"

\footnotetext{
${ }^{10}$ Both governors and/or relevant PBC staff are available to speak to journalists. The PBC's governor gave 63 percent of 86 speeches delivered by the governor/deputy governors between 2007 and end of 2017. Out of 140 press conferences during the same period, the governor took questions or gave interviews in about 20 percent of them. Oral communication surged in 2015-16, when important policy changes took place, such as interest rate liberalization, changes in the exchange rate regime, and a sharp adjustment in equity prices. Communication tends to be more ex post and with a focus on explanations rather than guiding expectations, reflecting - among other things - China's unique institutional setup and the PBC's lack of operational independence.

${ }^{11}$ The PBC started conducting weekly open market operations in 2003 and bi-weekly since 2004.

${ }^{12}$ From 2017 until June 30, 2018, the PBC published 179 such notes, 122 of them on days with open market operations.
} 
and would "strengthen its policy interpretation and information disclosure, deliver its policy intensions in a timely way and reasonably guide market expectations" (PBC 2018a). As part of the response to the increasing demand for timely information, the $\mathrm{PBC}$ now also communicates regularly through social media, such as Weibo (China's Twitter equivalent). As Figure 6 shows, within only a few years the PBC has already reached a very large following in both absolute and per capita numbers, compared with major central banks.

Figure 6. Central Bank Social Media Presence (Thousands, right scale Percent)

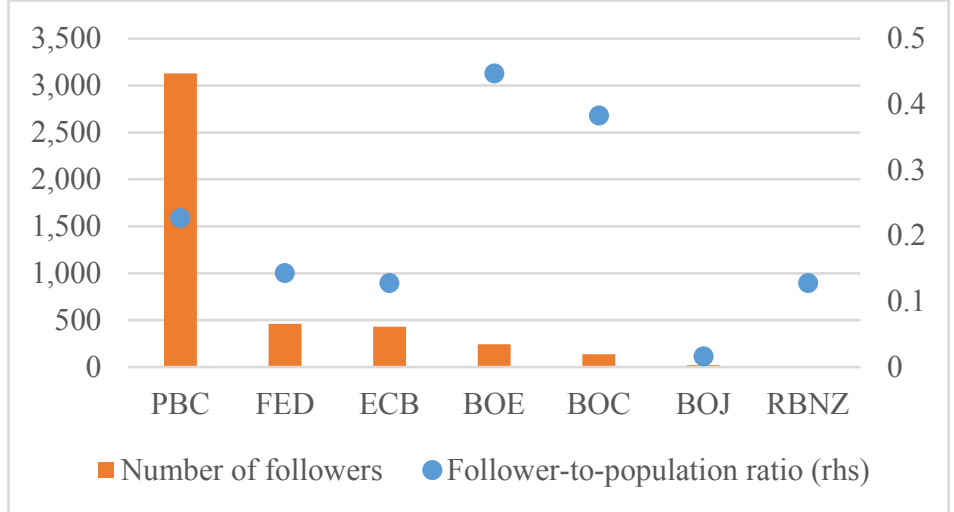

Source: Twitter accounts of FED, ECB, BOE, BOC, BOJ, and RBNZ; Weibo account of $P B C$; World Development Indicators (WDI).

\section{Box 1. Communication Terminology}

\section{Monetary Policy Stance}

As in other central banks, the People's Bank of China uses specific terminology to communicate its policy stance. The signaling, however, is quite infrequent (usually during the Work Conference in December) and requires State Council approval.

Five categories can be identified ${ }^{1}$ : (1) moderately loose, (2) moderately tight, (3) tight, (4) prudent, and (5) prudent and neutral. While categories (1) to (3) are straightforward, the distinction between "prudent" and "prudent and neutral" is more ambivalent, with the latter assumed to be somewhat tighter than "neutral". To visualize the potential relationship between the respective monetary policy stances and policy interest rates (the DR007 is one of the important benchmark rates, but has not yet been confirmed as a policy interest rate), the following scoring is used: -1 for "moderately loose", 0 for "prudent", +0.5 for "prudent and neutral", +1 for "moderately tight" and +2 for "tight". In Figure 1.1, the grey line shows the monetary policy stance, the blue line shows changes in the benchmark lending rate maturing in 6 months to 1 year, and the orange line is the 7-day reverse repo open market operations rate. 


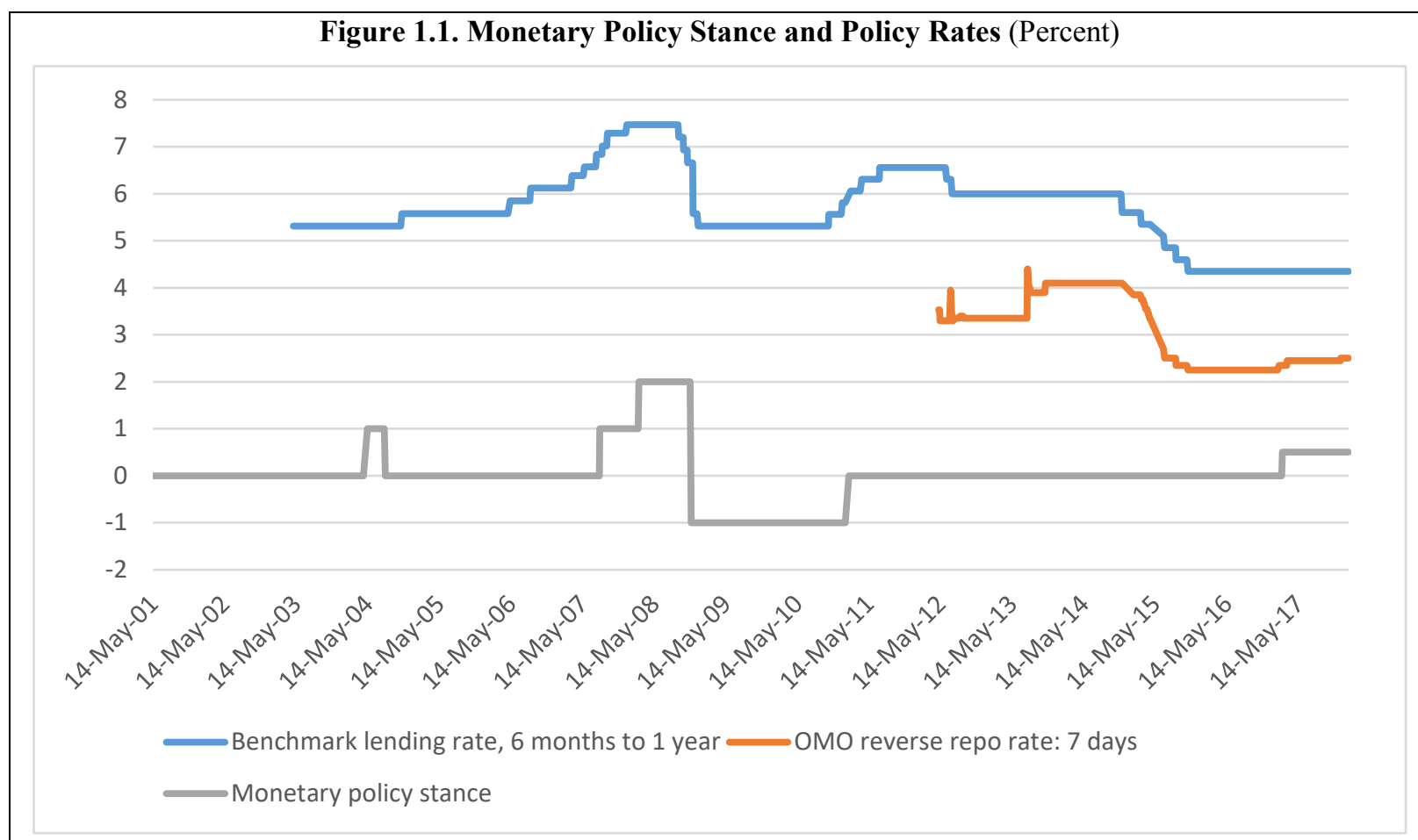

Source: CEIC.

Changes in language about the monetary stance in MPERs tend to be associated with changes in the benchmark interest rate; a positive change in the score, reflecting a tightening, is associated with an increase in benchmark interest rates (in the following quarter), and vice versa. However, as the figure shows, at times communication lags the actual decision about a benchmark rate change.

That terminology provides the PBC with significant flexibility and is reflected in the fact that during "prudent" monetary policy stance, the benchmark interest rate has both increased and decreased.

\section{Window Guidance}

In addition to written and oral communication disseminated publicly, the PBC provides "guidance" to financial institutions that impact their behavior. Among other things, this "window" guidance can be related to credit growth, lending to priority sectors, and so on. It can be an effective tool, but it undermines transparency and interest rates as the main signal of monetary policy conditions.

${ }^{5}$ See Zhou (2016) for a classification. The term "prudent and neutral" was added for the first time at the beginning of 2017 . 


\section{Literature REVIEW}

An increasing body of literature is studying the effect of central bank communication. Existing research focuses on the central banks in developed economies, mostly the U.S. Federal Reserve Bank, the European Central Bank, and the Bank of England. Generally speaking, these analyses examine the effects of monetary policy announcements, minutes of monetary policy committee meetings, regularly published reports, interviews and speeches, and congressional testimony or parliamentary committee hearings. Blinder and others (2008) is an early survey of the literature. Our paper follows much of this literature and relies on market-based event studies. ${ }^{13}$ Specifically, we investigate whether PBC communication affects asset prices on China's financial market in a manner indicating that the communication contains information.

Some analysis codes the communication contents by subjectively assigning values to the texts that are perceived as dovish or hawkish (Jansen and De Haan 2005; Ehrmann and Fratzscher 2007; Berger, Nitsch, and Lybek 2006), or using semantic orientation and text classification to quantify dimensions of the text (Lucca and Trebbi 2009; Hansen and McMahon 2016; Hansen, McMahon, and Prat 2018). These techniques are useful in identifying the direction of communication and can augment the type of analysis that we undertake in this paper. However, two obstacles hamper applying these methods to the Chinese language. First, dictionary methods do not work well for China given the different language structure. Second, communication from the PBC, especially in public speeches, is non-committal and tends to be carefully drafted. Garcia-Herrero and Girardin (2013), compute subjective "hawkish" and "dovish" scores for previous PBC Governor ZHOU Xiaochuan and monetary policy committee member FAN Gang. But such a manual coding approach can only be applied to small amounts of communication and restricting the analysis coverage may come with the risk of biased results. Hence, we focus on the fact that PBC officials come out to speak more than we do on the content of their speech, but we believe that further text analysis is an important direction for future studies on PBC communication.

Central bank communication in emerging economies has only more recently attracted greater attention. For example, Luangaram and Wongwachara (2017) implement text analysis techniques previously applied for advanced economies to analyze communication by the Bank of Thailand. For China, Garcia-Herrero and Girardin (2013) use the hawkish/dovish communication classification described above to test the impact of PBC communication on repo-market volatility and trading volume. Shu and $\mathrm{Ng}$ (2010) compile indices reflecting the direction and intensity of the PBC's monetary stance based on the quarterly monetary policy executive reports and monetary policy committee meeting minutes. Sun (2013) studies the impact of PBC communication on the macroeconomy, including GDP, inflation, and industrial output.

\footnotetext{
${ }^{13}$ A prominent paper in the event-study analysis of communication is Gürkaynak, Sack, and Swanson (2005), which focuses on Federal Reserve monetary policy announcements. Kohn and Sack (2003) examined the effects of a broader set of Federal Reserve communications. Reeves and Sawicki (2007) carried out similar analysis for the Bank of England Inflation Report. More recently, Hansen, McMahon, and Tong (2018) show that central bank communication on risks and uncertainty are an important source of information for long-maturity yields. See also Tobback, Nardelli, and Martens (2017).
} 
This paper contributes to the existing literature in the following ways: First, it comprehensively reviews China's unique institutional setting, which is paramount to understanding its evolving communication channels. Second, in addition to communication tools analyzed elsewhere (that is, quarterly monetary policy executive reports, quarterly monetary policy committee meeting minutes, as well as speeches and interviews), the study is novel in that it includes OMO notices. As discussed in Section III, the PBC considers these informative notices an important communication tool and started including them in 2016 (socalled "small notes"). Third, we analyze the transmission of communication to different markets.

\section{EMPIRICAL ANALYSIS}

The empirical event study focuses on whether PBC communications contain news for financial market variables. Consistent with the central bank communication literature, we are interested in the effect of communication on the intermediate target of monetary policy, that is, short-term interest rates. The first step is to construct variables that capture PBC communication events. As summarized in the previous section, the PBC communicates with the market in four main ways: (1) quarterly MPERs; (2) monetary policy committee meeting minutes (Minutes); (3) press conferences and speeches by the governor, deputy governors, and the then-chief economist of the PBC Research Bureau (Oral); and (4) informative OMO notices. We search the PBC's website and collect the date and time at which the MPER, minutes, press conference transcripts, texts of speeches, or OMO notices are posted. This information allows us, for every trading day, ${ }^{14}$ to create a dummy variable for each communication format: $D(M P E R), D$ (Minutes), D(Oral), and D(OMO Notice), with 1 indicating $\mathrm{PBC}$ communicates with the market in a certain format and 0 otherwise. We also construct an aggregate dummy $D(P B C$ Communication) which is 1 if the $\mathrm{PBC}$ has conducted at least one of the four communication formats, and 0 otherwise. For the oral communication, we are interested in whether the effect of communication from the governor differs from that of others, and so we also document the person who attended the press conference or who delivered the speech. Hence, we disaggregate $D($ Oral $)$ into $D($ Oral - PBCGOV $)$ and D(Oral Others).

Short-term money market rates are an important focus for the PBC. We therefore analyze the effects of communication on the Shanghai Interbank Offered Rate (SHIBOR), the collateralized interbank repo rate between depository financial institutions (DR007), and the collateralized interbank repo rate between all financial institutions (R007). Moreover, we are interested in the impact of the PBC's communication on short-term and medium-term commercial paper (STN and MTN), treasury bonds, and equity markets. The table 1 in Section II lists the details of these market rates.

To control for other factors that may affect market interest rate movements, we include (1) a dummy variable $D$ (Macro Release) to indicate the release of the main macroeconomic indicators, including the consumer price index (CPI), GDP, Official Purchasing Manufacturing

\footnotetext{
${ }^{14}$ When the post time is between 3:00 pm and 9:00 am the following morning, we adjust the date to the next trading day.
} 
Index and Caixin Purchasing Manufacturing Index (PMI), foreign trade and foreign exchange reserves; (2) a dummy variable $D(C E W C)$ to indicate the date of the government's annual Central Economic Work Conference, which determines the direction of economic policy for the following year ${ }^{15}$; and (3) a dummy variable $D$ (Rate Change) to indicate changes in PBC monetary policy instruments. In case of the latter, we include changes in the benchmark interest rate, required reserve ratio, $\mathrm{OMO}$, and other instrument rates, that is, the standing lending liquidity facility (SLF), short-term liquidity operations (SLO), medium-term lending facility (MLF), and the pledged supplementary lending (PSL).

Our event-study analysis covers trading days during 2013-17. We report summary statistics for the explanatory variables in Table 1.1, including communication and control variables, and various market rates in Table 1.2. On average, the PBC communicated with the market on about 25 percent of all trading days. Speeches or press conferences are the most common format of communication, taking place nearly every six trading days (16.1 percent of days in the sample). OMO information notices are next most frequent, occurring on 7.8 percent of the days, but they have become much more frequent since February 2017. Monetary Policy Executive Reports represent 1.6 percent, and monetary policy committee meeting minutes 1.5 percent. ${ }^{16}$ On days with communication, the average interest rates of the key assets are higher, reflecting more communication towards the end of our sample, when interest rates had risen. The standard deviations of these rates seem to be larger for longer- and smaller for shorterterm assets than on days without communication.

We first plot the kernel density of the daily absolute change of the DR007 (Figure 7) and 3-month short-term notes (Figure 8) for various categories of communication. These plots show that both communication and control variables indeed have some impact on market prices. Surprisingly, minutes releases are associated with news for repo rates (DR007), but this effect is not reflected in short-term notes. Oral communication, PBC interest rate changes, and OMO notices are associated with relatively higher market reaction for both assets.

\footnotetext{
${ }^{15}$ There are other regularly-held meetings at the central level such as the Politburo meetings, which may also have implications for monetary policy. By adding a dummy variable to indicate the date of the politburo meetings with economic issues discussed, we find that the politburo meetings do not significantly affect the financial market rates and this additional variable does not affect the results of PBC communication(results are available upon request). So we do not control the politburo meetings in the following analysis to keep a concise specification.

16 Since 2018, the PBC has already taken additional measures to further strengthened policy transparency and communication by timely responding to public concerns and guiding market expectation. For instance, to better explain the rational of OMOs, the PBC has released 85 pieces of notices during the 123 trading days in the first half of 2018. In addition, the PBC has strengthened traditional channels, such as more press conferences (17 press conferences or interviews during the first six months of 2018), deeper analysis and more informative Monetary Policy Executive Reports.
} 
Figure 7. Kernel Density of Daily Absolute Changes of DR007

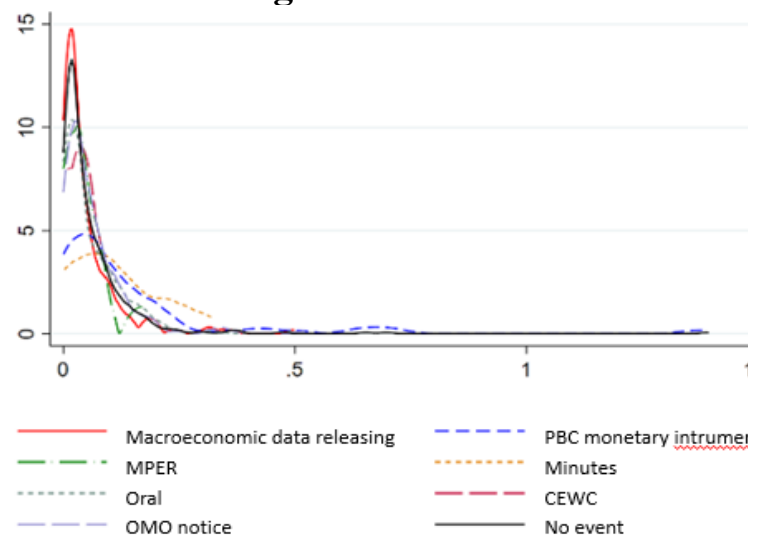

Source: Authors' calculations.
Figure 8. Kernel Density of Daily Absolute Changes of 3-Month Short-term Notes

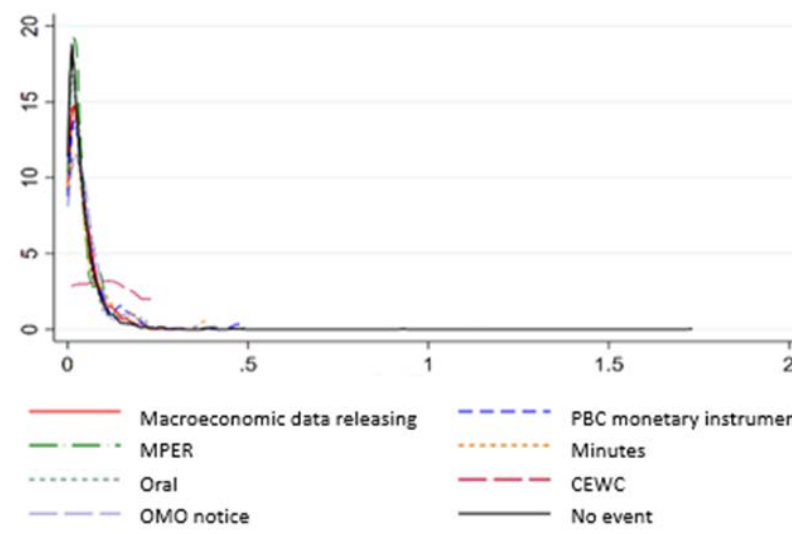

\section{V.1 Baseline Results: OLS Analysis of Communication News}

First, we conduct an ordinary least squares (OLS) analysis by estimating the following equations:

$$
\begin{aligned}
& \left.\left|\Delta r_{t}\right|=\alpha+\beta \mathrm{D}(\text { Communication })_{t}+\gamma_{1} \mathrm{D} \text { (Macro Release }\right)_{t}+\gamma_{2} \mathrm{D}(\mathrm{CEWC})_{t} \\
& +\gamma_{3} \mathrm{D}(\text { Rate Change })_{t}+\varepsilon_{t} \\
& \left|\Delta r_{t}\right|=\alpha+\beta_{1} \mathrm{D}(\text { MPER })_{t}+\beta_{2} \mathrm{D}(\text { Minutes })_{t}+\beta_{3} \mathrm{D}(\text { Oral }- \text { PBCGOV })_{t} \\
& +\beta_{3} \mathrm{D}(\text { Oral }- \text { Other })_{t}+\beta_{4} \mathrm{D}(\text { OMO Notice })_{t}+\gamma_{1} \mathrm{D}(\text { Macro Release })_{t} \\
& +\gamma_{2} \mathrm{D}(\mathrm{CEWC})_{t}+\gamma_{3} \mathrm{D}(\text { Rate Change })_{t}+\varepsilon_{t}
\end{aligned}
$$

These regressions, as in other event studies, identify the average reaction of market prices to the different types of communication events; the identifying assumption is that any systematic reaction on communication days is driven by the communication event. The dependent variable is, as for the Kernel densities, the daily absolute change in market rates. The advantage of using the absolute value is that we measure the market reaction to the communication irrespective of the direction of that reaction. The key test concerns the sign of the communication event dummy variable. When communication is associated with news, it would cause a market adjustment and thus positive $\beta$ coefficient. If, however, a communication event systematically reduced the noise in the market, it would be associated with less market adjustment than on other trading days and our estimated $\beta$ coefficient would be negative.

The key estimation results, correcting the standard errors using the Huber-White sandwich estimators, are presented visually in Figures 9 and 10; the full regression results are presented in appendix Tables 1.3 and 1.4.

Figure 10 suggests that $\mathrm{PBC}$ communication mainly affects short-term assets, while neither monetary policy instruments nor communication systematically move longer-term markets much, at least in a single days' time frame. More specifically, the main results are the 
following:

- First, as expected, policy instrument changes are associated with market news. However, PBC communication, in general, does not move the market too much, suggesting that the effectiveness of PBC communication is somewhat limited. As reflected in Table 1.3, the coefficients of $\mathrm{D}$ (Rate Change) are significantly positive for all assets with maturities less than 3 months, while the coefficients of D(PBC Communication) are only significant for the volatility of 1-week Shibor and 1-month short-term notes. Communication slightly calms markets, but does not move the market much.

- Second, the release of quarterly monetary policy executive reports tends to reduce the volatility of short-term notes. It acts as an important channel for the PBC to communicate with the market, as it contains a lot of operational details and sometimes forward-looking guidance, though not very often. From Table 1.3 and 1.4, MPERs are associated with a decline of 0.03 percentage points in the absolute change of 1-month short-term notes and 0.01 percentage points in that of 3-month short-term notes.

Figure 9. Estimated Coefficients of Aggregated Communication Events

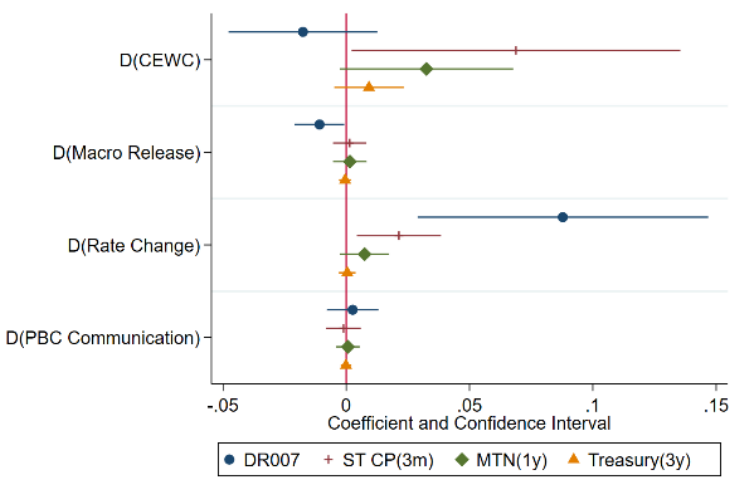

Figure 10. Estimated Coefficients of Disaggregated Communication Events

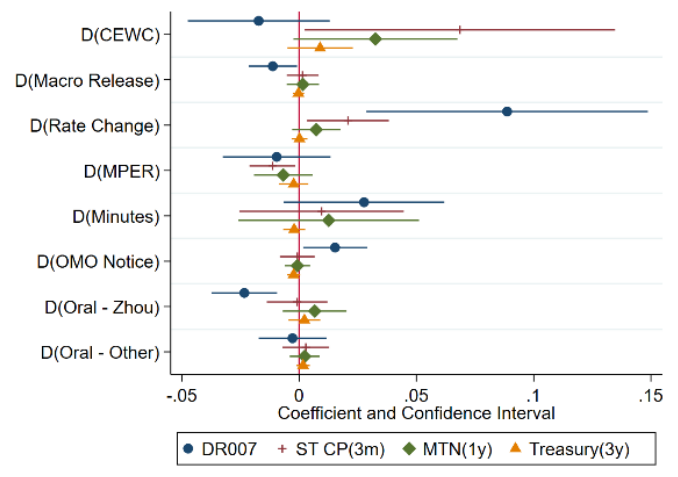

Source: Authors' calculation.

- Third, oral communication of public speeches, as well as press conferences, appear to calm the market. As Table 1.3 shows, oral communication is associated with a decrease in the market news of Shibor 1week, and 1-month short-term notes. Table 1.4 shows that for the PBC's DR007 target rate, communication events by the governor, either speeches or press conferences, is associated with 0.023 percentage points less market movement. However, oral communication is irregular, and the timing of oral communication is usually determined by market conditions. 


\section{V.2 Effect on Volatility and the Timing of Communication}

Even if there is no systematic effect on the average price in the market, another possibility is that communication events are associated with greater market volatility. OLS regressions do not separately model the volatility of the residuals; the regressions analysis above did correct the standard errors on coefficients for heteroskedasticity and autocorrelation. General Autoregressive Conditional Heteroscedastic (GARCH) models will allow us to address the possibility that time-series models may violate homoscedasticity (constant variance of errors). These models are used extensively in financial econometrics as higher frequency data tend to have periods of higher and lower volatility.

Specifically, we follow Nelson (1991), and explore the volatility effects of communication using an EGARCH methodology (a particular class of GARCH model). The advantage of an EGARCH model over a GARCH model is that it ensures that the conditional variance is positive and allows for the asymmetric response of the volatility to good and bad news. Our EGARCH( $(1,1)$ specification features a conditional mean equation in which it is necessary to control for all the relevant variables that drive the mean to minimize the size and variance of residuals:

$$
\Delta r_{t}=\gamma_{0}+\gamma_{1} x_{t}+\varepsilon_{t}
$$

where $\varepsilon_{t} \sim N\left(0, \sigma_{t}^{2}\right)$ and $x_{t}$ contains any controls in the conditional mean equation. The conditional volatility equation, which measures the drivers of $\sigma_{t}^{2}$, is:

$\log \sigma_{t}^{2}=\alpha_{0}+\sum_{k} \theta_{k} \mathrm{D}\left(\mathrm{Comms}_{k}\right)_{t}+\alpha_{1}\left(\frac{\varepsilon_{t-1}}{\sigma_{t-1}}\right)+\lambda\left(\left|\left(\frac{\varepsilon_{t-1}}{\sigma_{t-1}}\right)\right|-\sqrt{\frac{2}{\pi}}\right)+\phi \log \sigma_{t-1}^{2}$

where $\mathrm{D}\left(\mathrm{Comms}_{k}\right)_{t}$ indicates one of $k$ included communication dummy variables, described above.

To study the volatility effects while also ensuring that the dependent variables are stationary, we use the daily change of interest rates as the main dependent variable $\left(\Delta \boldsymbol{r}_{\boldsymbol{t}}\right)$. (Earlier, we focused on the market news given by the absolute value of the change in the interest rate). Given that the communication variables are dummy variables which could have a positive or negative effect on the level of the interest rate (depending on the message in the communication), in the mean equation we control for the lag of the dependent variable $\left(\Delta \boldsymbol{r}_{t-1}\right)$ and the change in the 7-day repo rate, but not for the communication event dummies.

Instead, we allow the communication events to affect volatility. However, as the EGARCH model is a nonlinear model, it does not always have a smooth likelihood function that is easily maximized. To ensure convergence of our estimates, we explore more parsimonious models in this section than we did earlier. In particular, we first explore the volatility effects of each of the four main communication events as used in (1) above. We then explore a more disaggregated approach but focus on the marginal effects (over the average communication event) of $\mathrm{D}(\mathrm{MPER})$ and $\mathrm{D}(\mathrm{Oral}$ - PBCGOV).

An average PBC communication is associated with higher volatility of short-term market rates (R007). When we disaggregate the effect a bit further, we find that this association is particularly strong for speeches by the PBC governor. However, one needs to be cautious with the interpretation of these findings. Especially for ad hoc events (such as an 
irregular press conference or speech), it could be that the volatility in the market leads the PBC to feel the need to comment. Even if the comment is calming, volatility could remain higher than usual and so the event is associated with high volatility. The EGARCH attempts to control for this by modelling volatility as dependent on the volatility from the previous trading day as well as other covariates.

The alternative interpretation of these results is that the event causes this higher volatility. When the $\mathrm{PBC}$ initiates ad hoc communication, the markets get the message of the communication and that the situation was severe or worrying enough to warrant communication. Regular communication allows markets to focus on the message being delivered since the date for the message is set in advance as is the case with the Bank of England inflation report or U.S. Federal Open Market Committee meetings.

An advantage of the EGARCH is that it provides an estimate of the conditional variance $\left(\widehat{\boldsymbol{\sigma}}_{\boldsymbol{t}}^{\mathbf{2}}\right)$ from each asset market. Figures 11 and 12 show this estimated conditional variance for the 7 -day repo market and the Treasury ( 3 year) market. These figures, augmented with indicators of speeches by the PBC governor, highlight that it is likely that both explanations are present in the data. In particular, speeches tend to be made irregularly and around higher volatility (as well as after the liberalization of interest rate markets in 2016). In some cases, the speeches are followed by increased volatility, and in others volatility falls from elevated levels.

Figure 11. 7-Day Repo Volatility

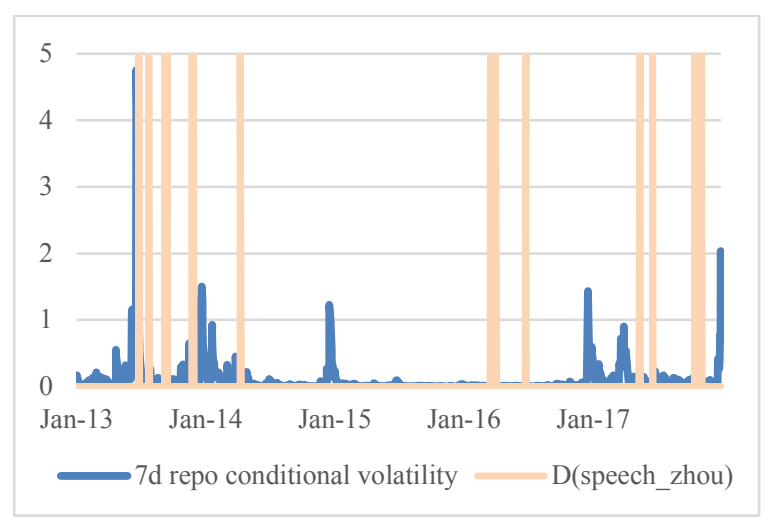

Figure 12. Treasury 3-Year Volatility

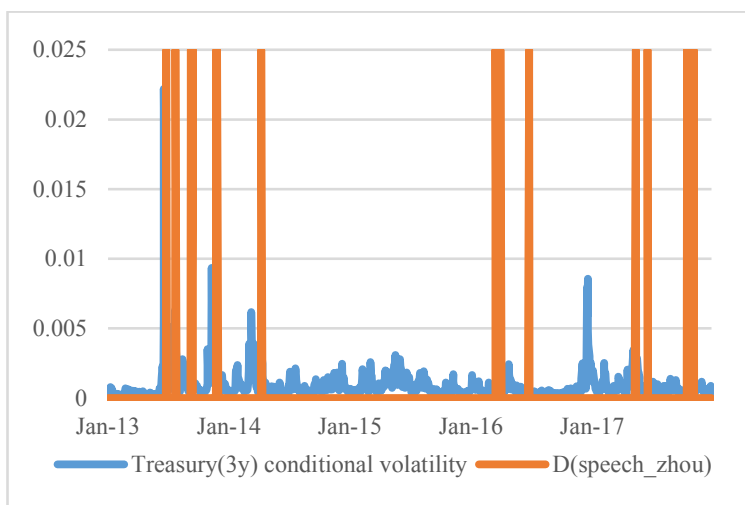

Source: Authors' calculations.

\section{V.3 Use and Impact of OMO Notices}

OMOs are the important way in which the PBC intervenes in the market. The transmission efficiency from OMO interest rates to the targeted market rates largely determines how monetary policy works. Like other central banks, the PBC conducts OMO frequently and publishes OMO notifications on its website. Usually OMO notices plainly state that the PBC has conducted OMOs at a specific interest rate and amount. The frequency of OMO actions is shown in Figure 13 as the teal triangles. In our sample of 1,249 trading days, the PBC conducted OMO interventions on 639 of them. 
Since March 2016, however, the PBC at times has added short sentences about market performance (that is, about liquidity and volatility) to explain the reason behind the OMOs, including information about the injection or withdrawal of liquidity, or even the reason for not intervening in the market. ${ }^{17}$ These informative OMO notices, compared to the standard ones, are seen as "small notes" passed from the PBC to the market, and we identify it as a format of the PBC's communication. The dummy $D(O M O$ Notice) takes the value of 1 when $\mathrm{PBC}$ publishes an informative notice, including brief rationales of the PBC's OMO decision. Otherwise the value is 0 . There were 98 informative notices in our sample. The first two were in March 2016 and then there was another one in October 2016; they started regularly in February 2017. Many of the notices (68) are issued on days when the PBC does not conduct an OMO action and the notice explains the reasons for the lack of action.

The last type of market intervention by the PBC that we examine are changes to the OMO interest rate. We define the dummy $D(O M O$ Rate Change) equal to 1 if the $\mathrm{PBC}$ changed any rates of the repo, reverse repo, and the $\mathrm{PBC}$ bill at any tenor. This differs from $\mathrm{D}$ (Rate Change) used previously, which documents, in addition to changes in OMO rates, changes in benchmark interest rates, the required reserve ratio, and the other instrument rates such as the short-term liquidity facility, MLF, and so on. In our sample, there were 37 trading days on which the PBC changed an OMO rate. All of these were associated with OMO actions on the same day, while only 2 of these occurred with OMO informative notices.

\section{Figure 13. PBC Market Interventions}

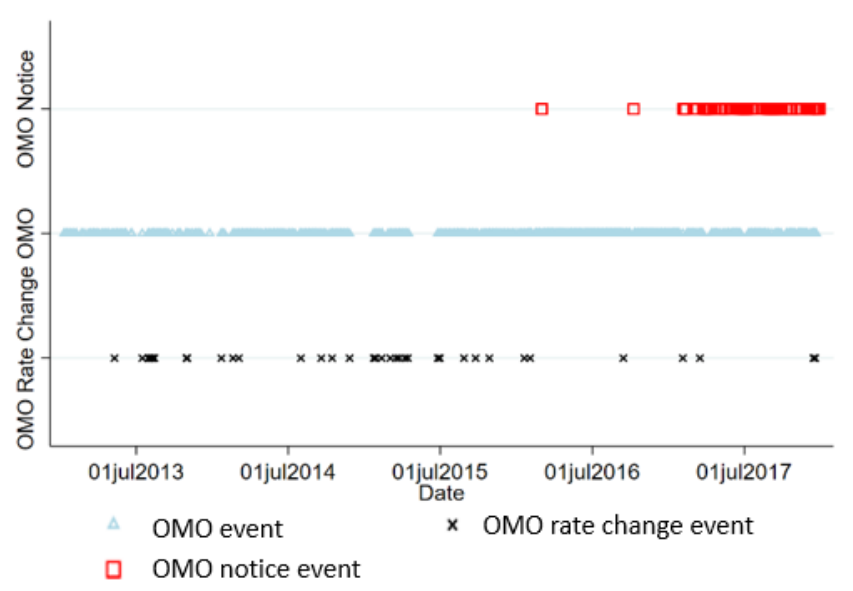

Source: People's Bank of China.

The PBC OMO notices allow us to study the effect of their communication on monetary policy transmission efficiency. Efficient OMO transmission would ensure that interest rates in the market moved relatively in step with the rates engineered by the central bank through market operations. To explore this, we examine the co-movement of market interest rates

\footnotetext{
17 The oldest notification dates back to January 2004. The PBC conducted OMOs weekly before May 2004, then adjusted the frequency to bi-weekly until January 2016. From 2016 to 2017, the PBC published OMO notifications daily, even for days without OMOs. Informative OMO notices started in March 2016.
} 
$\left(\Delta r_{t}^{m k t}\right)$ with OMO interest rates and explore how this differs during the period during which the PBC was issuing informative notices. We define a dummy D(Notice Era), which is 1 during the period after which the $\mathrm{PBC}$ was regularly issuing these informative notices, that is February 2017. The reason to focus on the period of regular notices is that once the market comes to expect and understands such communication, a trading day without a note is informative. The specification we use is:

$$
\Delta r_{t}^{m k t}=\alpha_{1}+\alpha_{2} \mathrm{D}(\text { Notice Era })_{t}+\beta_{1} \Delta r_{t}^{O M O}+\beta_{2} \mathrm{D}(\text { Notice Era })_{t} \times \Delta r_{t}^{O M O}+\varepsilon_{t}
$$

Without the interaction term, the estimated coefficient $\beta_{1}$ indicates that if the OMO rates increase by 1 percentage point (all rates are represented in percentage), the money market rates will increase by $\boldsymbol{\beta}_{\mathbf{1}}$ percentage points; stronger transmission of OMO rates would be captured by larger reaction of market rates, although values over 1 would indicate an overreaction. The estimated coefficient $\beta_{2}$, on the interaction term, captures the marginal change in this relationship in the era of the $\mathrm{PBC}$ issuing informative notices. A positive and statistically-significant $\beta_{2}$ coefficient indicates that the PBC's communication from the informative $\mathrm{OMO}$ notice has strengthened the transmission efficiency from the $\mathrm{OMO}$ rate to the market rate.

The results are presented in Table 1.7. The era of issuing informative notices has been associated with a stronger transmission of OMO rates to other market rates. Not unexpectedly, given we are looking at a 7-day reverse repo interest rate as the OMO rate, the results are strongest at the short end of the yield curve. Nonetheless, there has been a stronger co-movement, even with 1-year Shibor rates since the OMO notices have been issued.

A first concern is that the informative notice era coincides with the period following the liberalization. The overlap is not perfect; the PBC officially liberalized interest rates in October 2015, whereas the informative notices only became regular in February 2017. We consider two alternative approaches. First, we examine the correlation on the days on which an informative notice is issued; we replace $\mathrm{D}($ Notice Era) with $\mathrm{D}(\mathrm{OMO}$ Notice) in equation (5). ${ }^{18}$ The results, not reported here for the sake of brevity, are similar. A second approach is to estimate the regression in equation (5) but limiting the sample to the period after October 2015.

Another concern might be that rather than strengthen the transmission, the notices have simply sped up the pass through from OMO interest rates to other market interest rates. The regression analysis above only considers the contemporaneous correlation between market and OMO interest rates. To explore the dynamic effects, we can allow for lags of OMO interest rates to drive the market interest rates. To limit the number of interactions, we need to estimate the following specification, estimated separately for the era before and after informative notices were regularly issued:

\footnotetext{
${ }^{18}$ The alternative equation is: $\Delta \mathrm{r}_{\mathrm{t}}^{\mathrm{mkt}}=\alpha_{1}+\alpha_{2} \mathrm{D}(\text { OMO Notice })_{\mathrm{t}}+\beta_{1} \Delta \mathrm{r}_{\mathrm{t}}^{\text {OMO }}+\beta_{2} \mathrm{D}(\text { OMO Notice })_{\mathrm{t}} \times \Delta \mathrm{r}_{\mathrm{t}}^{\text {OMO }}+\varepsilon_{\mathrm{t}}$
} 


$$
\Delta r_{t}^{m k t}=\alpha_{1}+\sum_{j=0}^{T} \beta_{j} \Delta r_{t-j}^{O M O}+\varepsilon_{t}
$$

Table 1.8 presents the relevant estimation results. We find that the transmission in the change of the rate is not simply about faster transmission. Instead, we conclude that the transparency from using informative OMO notices has strengthened the transmission channel from $\mathrm{PBC}$ intervention to the market. We believe that understanding the rationale behind the PBC's change in the OMO rate, or reason for not intervening in markets, tends to help the market understand the policy better and reduce the noise.

\section{Policy Recommendations}

Our empirical analysis suggests that while the PBC has made a number of important improvements to its communication, the timing for strengthening communication still further, and associated institutional changes, is propitious.

Institutional changes take time and require resources and political capital. But as China develops its financial system, particularly market-based financing, the need for transparent, clear, timely, and comprehensive communication will continue to increase. Failure to address existing institutional shortcomings may limit the benefits of liberalization and slow economic development.

While larger institutional changes will take time, practical actions could improve communication in advance. In fact, these suggestions are better if implemented in advance of or at least in tandem with greater operational independence. For example, the Bank of England first published its Inflation Report in February 1993 when it did not have control over U.K. monetary policy. When it became operationally independent in June 1997, the central bank's thinking and analytical tools were already well understood by the market. Lack of independence should hence not be viewed as a reason not to press ahead. As a matter of fact, certain "low-hanging fruit" could be implemented quickly:

- Making information available in a timely fashion, in one place, and in English would go a long way. This would also be consistent with the intention to make capital markets more attractive, as well as China's renminbi internationalization strategy, and its participation in global forums.

- Expanding PBC economic forecasting capacity and publishing forecasts regularly, as well as making information available about the associated framework and models. This would reduce surprises, making monetary policy more predictable. While the PBC's Research Bureau released economic forecasts in 2015 and 2016, each with a mid-year update, these were discontinued in 2017. Of course, strengthening forecasting would require appropriate resources and expertise; here the $\mathrm{PBC}$ could tap into the experience of modern central banks, as well as technical collaboration with the IMF. 
- Holding regular press conferences. A regular communication mechanism could reduce information asymmetry between the central bank and the market and allow markets to better interpret decisions and hence reduce uncertainty. As with forecasting, it is useful to begin these efforts even in advance of greater operational independence. Such a process will help the PBC learn how to communicate with the market directly and to build credibility that will serve it well, if it is - as is warranted - to become operationally more independent. ${ }^{19}$

\section{Conclusions}

Central banks are increasingly using communication as a lever of monetary policy and are often at the forefront of communication. The same is true for the $\mathrm{PBC}$, which has taken important steps to improve communication. Given China's global footprint and stated policies to further liberalize its financial system and continue moving toward price-based monetary policy, further improvements in communication will be critical.

We assess the impact of PBC's communication on financial markets using four types of communication: (1) the quarterly published Monetary Policy Executive Report, (2) the quarterly released Monetary Policy Committee Meeting Minutes, and (3) press conferences and speeches by governors and deputy governors; the fourth channel is novel and includes informative OMO notices. The daily absolute change of several market interest rates in the money and bond markets, as well as equity market prices, are calculated to represent market reaction. They are regressed on $\mathrm{PBC}$ communication and control variables to estimate whether PBC communication affects market reaction and volatility.

The empirical analysis highlights that communication can have important benefits and that greater central bank transparency and independence would help further improve PBC's effectiveness, including through forward guidance. The introduction of OMO information notices, for example, reduced volatility and improved monetary policy effectiveness. While some institutional changes are likely to take time, there are low-hanging fruits that could be adopted in the short term. For example, providing timely information in one place (in Chinese and English), expanding PBC forecasting resources and capacity, and holding regular press conferences would not only be helpful for monetary policy, but also increase the attractiveness of China's capital markets and advance renminbi internationalization.

In 2018, the PBC reiterated its commitment to further strengthen communication and transparency and has already taken additional steps, including through more press conferences and interviews, deeper analysis and more informative Monetary Policy Executive Reports, to guide market expectations.

\footnotetext{
${ }^{19}$ See IMF (2018a).
} 


\section{REFERENCES}

Adrian, Tobias, Douglas Laxton, and Maurice Obstfeld. 2018. "An Overview of InflationForecast Targeting." In Advancing the Frontiers of Monetary Policy, edited by Adrian, Tobias; Douglas Laxton, and Maurice Obstfeld, Washington, DC: IMF.

Berger, H., V. Nitsch, and T. Lybek. 2006. "Central Bank Boards Around the World: Why Does Membership Size Differ?” IMF Working Paper No. 2006-2281. International Monetary Fund, Washington.

Bernanke, B. S. 2007. "Federal Reserve Communications." Speech at the Cato Institute $25^{\text {th }}$ Annual Monetary Conference, Washington, D.C., November 14. https://www.federalreserve.gov/newsevents/speech/bernanke20071114a.htm.

Blinder, A. S., M. Ehrmann, M. Fratzscher, J. D. Haan, and D.-J. Jansen. 2008. "Central Bank Communication and Monetary Policy: A Survey of Theory and Evidence." Journal of Economic Literature, American Economic Association 46 (4): 910-45.

Dincer, N. N. and B. Eichengreen. 2014. "Central Bank Transparency and Independence: Updates and New Measures." International Journal of Central Banking 10 (1): 189-259.

Ehrmann, M., and M. Fratzscher. 2007. "The Timing of Central Bank

Communication.” European Journal of Political Economy 23 (1). 124-145.

Garcia-Herrero, A., and E. Girardin. 2013. "China's Monetary Policy Communication: Money Markets Not Only Listen, They Also Understand.” KKIMR Working paper No. 02/2013.

http://www.pbc.gov.cn/zhengwugongkai/127924/128038/128109/3544192/index.html.

Gürkaynak, R. S., B. Sack, and E. Swanson. 2005. "Do Actions Speak Louder Than Words? The Response of Asset Prices to Monetary Policy Actions and Statements." International Journal of Central Banking 1 (1).

Hansen, S. and M. McMahon. 2016. "Shocking Language: Understanding the Macroeconomic Effects of Central Bank Communication." Journal of International Economics 99 (S1): S114-S133.

Hansen, S., M. McMahon, and A. Prat. 2018. "Transparency and Deliberation within the FOMC: A Computational Linguistics Approach." The Quarterly Journal of Economics 133 (2): 801-870.

Hansen, S., M. McMahon, and M. Tong. 2018. "The Long-Run Information Effect of Central Bank Communication.” CEPR Discussion Paper. Centre for Economic Policy Research, London. 
Huang, Y., T. Ge, and C. Wang. 2018 "Monetary Policy Framework and Transmission Mechanism." Chapter in the Handbook of China's Financial System, Edited by Marlene Amstad, Guofeng Sun, Wei Xiong.

IMF 2018. "People's Republic of China Staff Report for the 2018 Article IV Consultation." IMF, Washington, D.C. https://www.imf.org/en/Publications/CR/Issues/2018/07/25/PeoplesRepublic-of-China-2018-Article-IV-Consultation-Press-Release-Staff-Report-Staff-46121.

Jansen, D. J., and J. De Haan. 2005. "Talking heads: The Effects of ECB Statements on the Euro-Dollar Exchange Rate.” Journal of International Money and Finance 24 (2): 343-361.

Kohn, D. L., and B. P. Sack. 2003. “Central Bank Talk: Does It Matter and Why?” Divisions of Research and Statistics and Monetary Affairs, Federal Reserve Board, Washington.

Li Keqiang. 2018. "Report on the Work of the Government." National People's Congress, Beijing.

Luangaram, P. and W. Wongwachara. 2017. "More than Words: A Textual Analysis of Monetary Policy Communication.” PIER Discussion Papers 54. Puey Ungphakorn Institute for Economic Research, Bangkok.

Lucca, D. O., and F. Trebbi. 2009. "Measuring Central Bank Communication: An Automated Approach with Application to FOMC Statements." NBER Working Paper No. w15367. National Bureau of Economic Research, Cambridge, MA.

Ma J. and T. Guan. 2018. "Interest Rate Liberalization and Reform of China's Monetary Policy Framework." China Financial Press (in Chinese).

MA Jun. 2017. "Interest Rate Transmission in a New Monetary Policy Framework." In Modernizing China's Monetary Policy Framework, edited by Lahm, W.R., M. Rodlauer, and Alfred Schipke. Washington, DC: IMF.

Nelson, D. B. 1991. "Conditional Heteroskedasticity in Asset Returns: A New Approach. Econometrica: Journal of the Econometric Society 59 (2): 347-370.

People's Bank of China (PBC). 2018a. "Information Disclosure and Transparency (in Chinese)." PBC, Beijing. May 23.

http://www.pbc.gov.cn/zhengwugongkai/127924/128038/128109/3544192/index.html.

- 2018b. "Q\&A of Governor Yi Gang at Sub-forum 'Monetary Policy Normalization' of BOAO Forum for Asia Annual Conference." Question and answer of the PBC governor. 2018. http://www.pbc.gov.cn/english/130724/3523967/index.html.

Reeves, R., and M. Sawicki. 2007. "Do Financial Markets React to Bank of England Communication?" European Journal of Political Economy 23 (1): 207-227. 
Shu, C., and B. Ng. 2010. "Monetary Stance and Policy Objectives in China: A Narrative Approach.” HKMA China Economic Issues 1 (10), 1-40.

Sun, R. 2013. "Does Monetary Policy Matter in China? A Narrative Approach." China Economic Review 26 (C): 56-74.

Tobback, E., S. Nardelli, and D. Martens. 2017. "Between Hawks and Doves: Measuring Central Bank Communication."

Zhou, Xiaochuan. 2016. Press Conference on Financial Reform and Development during the 2016 National People's Congress March 12, 2016. http://www.pbc.gov.cn/goutongjiaoliu/113456/113469/3030450/index.html.

Zhou, Xiaochuan. 2016. "Managing Multi-Objective Monetary Policy: From the Perspective of Transitioning Chinese Economy." The 2016 Michel Camdessus Central Banking Lecture, June 24, 2016, International Monetary Fund, Washington, DC. 


\section{APPENDIX 1}

Appendix Table 1.1. Statistics Summary for Communication and Control Variables

\begin{tabular}{l|cc}
\hline Variable & Mean & Sd \\
\hline D(CEWC) & 0.001 & 0.001 \\
D(MPER) & 0.015 & 0.015 \\
D(Minutes) & 0.015 & 0.015 \\
D(OMO Notice) & 0.038 & 0.038 \\
D(Macro Release) & 0.088 & 0.088 \\
D(Rate Change) & 0.116 & 0.116 \\
D(Oral - PBC Governor) & 0.015 & 0.015 \\
D(Oral Communication) & 0.059 & 0.059 \\
D(PBC Communication) & 0.119 & 0.119 \\
D(Oral - Other) & 0.044 & 0.044 \\
\hline
\end{tabular}

Source: Authors' calculation.

Table 1.2. Statistics Summary for Market Rates

\begin{tabular}{l|cc|cc}
\hline & \multicolumn{2}{|c|}{ Communication=0 } & \multicolumn{2}{c}{ Communication=1 } \\
\hline Variables & Mean & Sd & Mean & Sd \\
\hline R007 & 2.641 & 2.641 & 3.046 & 3.046 \\
DR007 & 2.722 & 2.722 & 2.746 & 2.746 \\
SHIBOR(1d) & 2.353 & 2.353 & 2.460 & 2.460 \\
SHIBOR(1w) & 2.925 & 2.925 & 2.908 & 2.908 \\
MTN(1y) & 4.064 & 4.064 & 4.164 & 4.164 \\
MTN(3m) & 4.138 & 4.138 & 4.080 & 4.080 \\
MTN(6m) & 4.206 & 4.206 & 4.153 & 4.153 \\
ST CP(1m) & 4.016 & 4.016 & 3.935 & 3.935 \\
ST CP(3m) & 3.860 & 3.860 & 3.980 & 3.980 \\
ST CP(6m) & 3.954 & 3.954 & 4.063 & 4.063 \\
Treasury(1y) & 2.635 & 2.635 & 2.919 & 2.919 \\
Treasury(5y) & 3.228 & 3.228 & 3.346 & 3.346 \\
Treasury(10y) & 3.567 & 3.567 & 3.559 & 3.559 \\
SSE Return & 0.013 & 0.013 & 0.096 & 0.096 \\
\hline Sour Aur
\end{tabular}

Source: Authors calculations. 
Table 1.3. OLS Estimates for Aggregated Communication

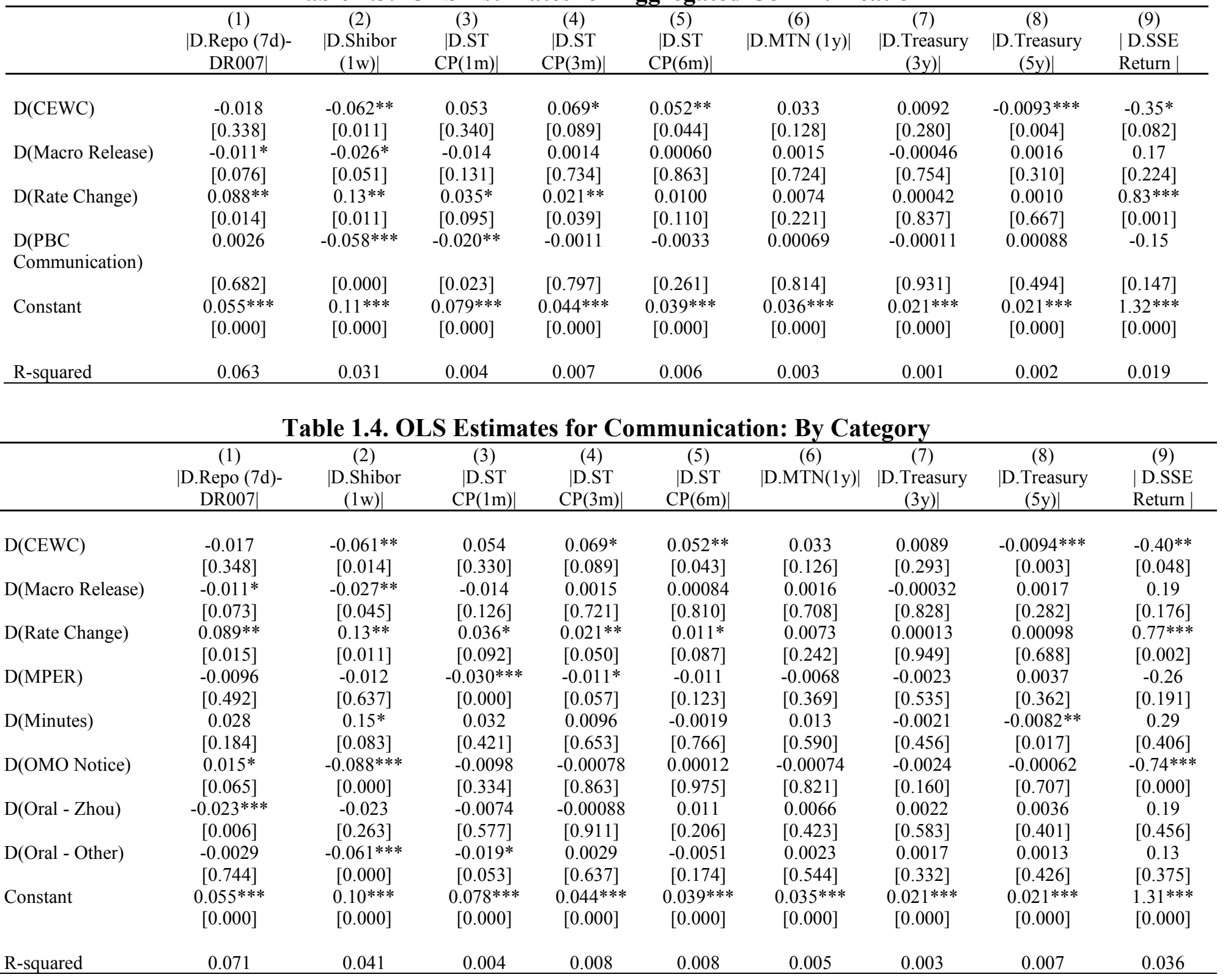


Table 1.5. EGARCH Results of Aggregated Communication

\begin{tabular}{|c|c|c|c|c|c|}
\hline & $\begin{array}{l}\text { D.R007 } \\
\text { (1) }\end{array}$ & $\begin{array}{c}\text { D.ST CP(3m) } \\
(2)\end{array}$ & $\begin{array}{c}\text { D.MTN(1y) } \\
\text { (3) }\end{array}$ & $\begin{array}{c}\text { D.Treasury (3y) } \\
\text { (4) }\end{array}$ & $\begin{array}{c}\text { SSE Return } \\
\text { (5) }\end{array}$ \\
\hline \multicolumn{6}{|l|}{ CONDITIONAL MEAN } \\
\hline Dependent Variable(t-1) & $\begin{array}{c}0.14 * * * \\
(0.000)\end{array}$ & $\begin{array}{l}0.18^{* * *} \\
(0.000)\end{array}$ & $\begin{array}{l}0.13^{* * *} \\
(0.000)\end{array}$ & $\begin{array}{l}0.07 * * * \\
(0.023)\end{array}$ & $\begin{array}{c}0.02 \\
(0.447)\end{array}$ \\
\hline D.Reverse Repo Rate & $\begin{array}{l}0.38^{* * *} \\
(0.024)\end{array}$ & $\begin{array}{c}-0.00 \\
(0.971)\end{array}$ & $\begin{array}{c}0.02 \\
(0.772)\end{array}$ & $\begin{array}{c}-0.02 \\
(0.490)\end{array}$ & $\begin{array}{c}0.36 \\
(0.873)\end{array}$ \\
\hline Constant & $\begin{array}{c}0.01 * * * \\
(0.000)\end{array}$ & $\begin{array}{c}0.00 \\
(0.492)\end{array}$ & $\begin{array}{c}-0.00 \\
(0.305)\end{array}$ & $\begin{array}{c}0.00 \\
(0.969)\end{array}$ & $\begin{array}{c}0.03 \\
(0.274)\end{array}$ \\
\hline \multicolumn{6}{|c|}{ CONDITIONAL VOLATILITY } \\
\hline $\mathrm{D}(\mathrm{CEWC})$ & $\begin{array}{l}2.44 * * * \\
(0.000)\end{array}$ & $\begin{array}{l}-0.43 \\
(0.422)\end{array}$ & $\begin{array}{c}-0.26 \\
(0.603)\end{array}$ & $\begin{array}{c}-0.87 \\
(0.146)\end{array}$ & $\begin{array}{l}0.46^{* * *} \\
(0.009)\end{array}$ \\
\hline $\mathrm{D}$ (Macro Release) & $\begin{array}{c}-0.43 * * * \\
(0.000)\end{array}$ & $\begin{array}{c}0.11^{*} \\
(0.076)\end{array}$ & $\begin{array}{c}0.04 \\
(0.432)\end{array}$ & $\begin{array}{c}-0.06 \\
(0.406)\end{array}$ & $\begin{array}{c}-0.02 \\
(0.514)\end{array}$ \\
\hline D(Rate Change) & $\begin{array}{c}0.06 \\
(0.302)\end{array}$ & $\begin{array}{c}0.28^{* * *} \\
(0.000)\end{array}$ & $\begin{array}{c}0.04 \\
(0.461)\end{array}$ & $\begin{array}{c}0.03 \\
(0.743)\end{array}$ & $\begin{array}{c}0.03 \\
(0.580)\end{array}$ \\
\hline $\mathrm{D}$ (PBC Communication) & $\begin{array}{c}0.08^{* * *} \\
(0.000)\end{array}$ & $\begin{array}{c}-0.01 \\
(0.873)\end{array}$ & $\begin{array}{c}-0.01 \\
(0.812)\end{array}$ & $\begin{array}{c}-0.00 \\
(0.949)\end{array}$ & $\begin{array}{c}-0.03 \\
(0.251)\end{array}$ \\
\hline Constant & $\begin{array}{c}-0.08^{* * * *} \\
(0.000)\end{array}$ & $\begin{array}{c}-0.36^{* * * *} \\
(0.000)\end{array}$ & $\begin{array}{c}-0.35 * * * \\
(0.000)\end{array}$ & $\begin{array}{c}-0.74 * * * \\
(0.000)\end{array}$ & $\begin{array}{c}0.02 * \\
(0.070)\end{array}$ \\
\hline $\mathrm{ARCH}$ & & & & & \\
\hline L.earch & $\begin{array}{c}0.25^{* * *} \\
(0.000)\end{array}$ & $\begin{array}{c}0.17 * * * \\
(0.000)\end{array}$ & $\begin{array}{c}0.08 * * * \\
(0.000)\end{array}$ & $\begin{array}{c}0.11 * * * \\
(0.000)\end{array}$ & $\begin{array}{c}0.01 \\
(0.384)\end{array}$ \\
\hline $\mid$ L.earch $\mid$ & $\begin{array}{c}0.36^{* * *} \\
(0.000)\end{array}$ & $\begin{array}{l}0.58^{* * *} \\
(0.000)\end{array}$ & $\begin{array}{c}0.30^{* * *} \\
(0.000)\end{array}$ & $\begin{array}{c}0.47 * * * \\
(0.000)\end{array}$ & $\begin{array}{c}0.20^{* * *} \\
(0.000)\end{array}$ \\
\hline L.egarch & $\begin{array}{l}0.96^{* * *} \\
(0.000)\end{array}$ & $\begin{array}{l}0.93^{* * *} \\
(0.000)\end{array}$ & $\begin{array}{l}0.94 * * * \\
(0.000)\end{array}$ & $\begin{array}{c}0.90^{* * *} \\
(0.000)\end{array}$ & $\begin{array}{l}1.00^{* * *} \\
(0.000)\end{array}$ \\
\hline Observations & 1246 & 1246 & 1246 & 1246 & 1159 \\
\hline
\end{tabular}

Note: $p$-values in parentheses

${ }^{*} \mathrm{p}<0.1,{ }^{*} \mathrm{p}<0.05, * * * \mathrm{p}<0.01$ 
Table 1.6. EGARCH Results of Aggregated Communication by Category and People

\begin{tabular}{|c|c|c|c|c|c|}
\hline & $\begin{array}{l}\text { D.R007 } \\
\text { (1) }\end{array}$ & $\begin{array}{c}\text { D.ST CP }(3 \mathrm{~m}) \\
(2)\end{array}$ & $\begin{array}{c}\text { D.MTN(1y) } \\
\text { (3) }\end{array}$ & $\begin{array}{c}\text { D.Treasury (3y) } \\
(4)\end{array}$ & $\begin{array}{c}\text { SSE Return } \\
(5)\end{array}$ \\
\hline \multicolumn{6}{|l|}{ CONDITIONAL MEAN } \\
\hline Dependent Variable(t-1) & $\begin{array}{l}0.14 * * * \\
(0.000)\end{array}$ & $\begin{array}{l}0.13^{* * *} \\
(0.000)\end{array}$ & $\begin{array}{l}0.14 * * * \\
(0.000)\end{array}$ & $\begin{array}{l}0.07 * * * \\
(0.023)\end{array}$ & $\begin{array}{c}0.03 \\
(0.431)\end{array}$ \\
\hline D.Reverse Repo Rate & $\begin{array}{l}0.36^{* *} \\
(0.039)\end{array}$ & $\begin{array}{c}0.00 \\
(0.983)\end{array}$ & $\begin{array}{c}0.02 \\
(0.798)\end{array}$ & $\begin{array}{c}-0.02 \\
(0.512)\end{array}$ & $\begin{array}{c}0.33 \\
(0.882)\end{array}$ \\
\hline Constant & $\begin{array}{l}0.01 * * * \\
(0.000)\end{array}$ & $\begin{array}{c}0.00 \\
(0.225)\end{array}$ & $\begin{array}{c}-0.00 \\
(0.209)\end{array}$ & $\begin{array}{c}0.00 \\
(0.992)\end{array}$ & $\begin{array}{c}0.03 \\
(0.245)\end{array}$ \\
\hline \multicolumn{6}{|c|}{ CONDITIONAL VOLATILITY } \\
\hline $\mathrm{D}(\mathrm{CEWC})$ & $\begin{array}{c}2.40^{* * *} \\
(0.000)\end{array}$ & $\begin{array}{c}-0.54 \\
(0.354)\end{array}$ & $\begin{array}{c}-0.13 \\
(0.834)\end{array}$ & $\begin{array}{c}-0.93 \\
(0.130)\end{array}$ & $\begin{array}{c}0.37 * \\
(0.055)\end{array}$ \\
\hline $\mathrm{D}$ (Macro Release) & $\begin{array}{c}-0.43 * * * \\
(0.000)\end{array}$ & $\begin{array}{c}0.06 \\
(0.414)\end{array}$ & $\begin{array}{c}0.06 \\
(0.342)\end{array}$ & $\begin{array}{c}-0.07 \\
(0.342)\end{array}$ & $\begin{array}{c}-0.03 \\
(0.485)\end{array}$ \\
\hline D(Rate Change) & $\begin{array}{c}0.06 \\
(0.271)\end{array}$ & $\begin{array}{l}0.45^{* * *} \\
(0.000)\end{array}$ & $\begin{array}{c}0.13^{*} \\
(0.057)\end{array}$ & $\begin{array}{c}0.02 \\
(0.858)\end{array}$ & $\begin{array}{c}0.03 \\
(0.542)\end{array}$ \\
\hline $\mathrm{D}$ (PBC Communication) & $\begin{array}{l}0.06^{* * *} \\
(0.009)\end{array}$ & $\begin{array}{l}0.09 * * \\
(0.026)\end{array}$ & $\begin{array}{c}-0.03 \\
(0.405)\end{array}$ & $\begin{array}{c}0.02 \\
(0.745)\end{array}$ & $\begin{array}{c}-0.02 \\
(0.450)\end{array}$ \\
\hline D(Oral-PBCGOV) & $\begin{array}{c}0.17^{*} \\
(0.095)\end{array}$ & $\begin{array}{c}-0.15 \\
(0.343)\end{array}$ & $\begin{array}{l}0.74 * * * \\
(0.000)\end{array}$ & $\begin{array}{c}-0.24 \\
(0.172)\end{array}$ & $\begin{array}{l}-0.16^{* *} \\
(0.026)\end{array}$ \\
\hline D(MPER) & $\begin{array}{c}-0.19 \\
(0.251)\end{array}$ & $\begin{array}{l}0.33^{* *} \\
(0.028)\end{array}$ & $\begin{array}{c}0.16 \\
(0.345)\end{array}$ & $\begin{array}{l}-0.07 \\
(0.751)\end{array}$ & $\begin{array}{l}-0.12 \\
(0.359)\end{array}$ \\
\hline Constant & $\begin{array}{c}-0.07^{* * * *} \\
(0.000)\end{array}$ & $\begin{array}{c}-0.88^{* * *} \\
(0.000)\end{array}$ & $\begin{array}{c}-0.56^{* * *} \\
(0.000)\end{array}$ & $\begin{array}{c}-0.73 * * * \\
(0.000)\end{array}$ & $\begin{array}{l}0.02 * * \\
(0.033)\end{array}$ \\
\hline $\mathrm{ARCH}$ & & & & & \\
\hline L.earch & $\begin{array}{l}0.24^{* * *} \\
(0.000)\end{array}$ & $\begin{array}{c}0.19^{* * *} \\
(0.000)\end{array}$ & $\begin{array}{l}0.09^{* * *} \\
(0.000)\end{array}$ & $\begin{array}{l}0.11^{* * *} \\
(0.000)\end{array}$ & $\begin{array}{c}0.01 \\
(0.424)\end{array}$ \\
\hline $\mid$ L.earch $\mid$ & $\begin{array}{l}0.36^{* * *} \\
(0.000)\end{array}$ & $\begin{array}{c}0.77^{* * * *} \\
(0.000)\end{array}$ & $\begin{array}{l}0.37 * * * \\
(0.000)\end{array}$ & $\begin{array}{l}0.47^{* * *} \\
(0.000)\end{array}$ & $\begin{array}{l}0.20^{* * *} \\
(0.000)\end{array}$ \\
\hline L.egarch & $\begin{array}{l}0.96^{* * *} \\
(0.000)\end{array}$ & $\begin{array}{c}0.84^{* * * *} \\
(0.000)\end{array}$ & $\begin{array}{l}0.91 * * * \\
(0.000)\end{array}$ & $\begin{array}{l}0.90^{* * *} \\
(0.000)\end{array}$ & $\begin{array}{l}1.00^{* * *} \\
(0.000)\end{array}$ \\
\hline Observations & 1246 & 1246 & 1246 & 1246 & 1159 \\
\hline
\end{tabular}

Note: $\mathrm{p}$-values in parentheses

$* \mathrm{p}<0.1, * * \mathrm{p}<0.05, * * * \mathrm{p}<0.01$ 
Table 1.7. OMO Notice and Transmission Efficiency

\begin{tabular}{|c|c|c|c|c|c|c|c|c|c|c|c|c|}
\hline VARIABLES & $\begin{array}{c}(1) \\
\text { D.R001 }\end{array}$ & $\begin{array}{c}(2) \\
\text { D.R007 }\end{array}$ & $\begin{array}{c}(3) \\
\text { D.DR007 }\end{array}$ & $\begin{array}{c}(4) \\
\text { D.R014 }\end{array}$ & $\begin{array}{c}(5) \\
\text { D.Shibor } \\
(1 d)\end{array}$ & $\begin{array}{c}(6) \\
\text { D.Shibor } \\
(1 \mathrm{w})\end{array}$ & $\begin{array}{c}(7) \\
\text { D.Shibor } \\
(2 \mathrm{w}) \\
\end{array}$ & $\begin{array}{c}(8) \\
\text { D.Shibor } \\
(1 \mathrm{~m})\end{array}$ & $\begin{array}{c}(9) \\
\text { D.Shibor } \\
(3 \mathrm{~m}) \\
\end{array}$ & $\begin{array}{c}(10) \\
\text { D.Shibor } \\
(6 \mathrm{~m})\end{array}$ & $\begin{array}{c}(11) \\
\text { D.Shibor } \\
(9 \mathrm{~m})\end{array}$ & $\begin{array}{c}(12) \\
\text { D.Shibor } \\
(1 \mathrm{y})\end{array}$ \\
\hline $\begin{array}{l}\text { D.Reverse Repo } \\
\text { Rate }\end{array}$ & -0.063 & -0.0097 & -0.0038 & -0.11 & $-0.045^{*}$ & 0.027 & $-0.15 * * *$ & $-0.12 * * *$ & -0.0069 & 0.0037 & 0.0019 & 0.0021 \\
\hline Notice Era & $\begin{array}{l}{[0.179]} \\
0.0071\end{array}$ & $\begin{array}{c}{[0.897]} \\
0.0089\end{array}$ & $\begin{array}{l}{[0.962]} \\
0.0034\end{array}$ & $\begin{array}{c}{[0.130]} \\
0.017\end{array}$ & $\begin{array}{c}{[0.091]} \\
0.0038\end{array}$ & $\begin{array}{c}{[0.772]} \\
0.0023\end{array}$ & $\begin{array}{c}{[0.008]} \\
0.0050\end{array}$ & $\begin{array}{c}{[0.002]} \\
0.0053\end{array}$ & $\begin{array}{c}{[0.582]} \\
0.0042 * *\end{array}$ & $\begin{array}{c}{[0.292]} \\
0.0044 * * *\end{array}$ & $\begin{array}{c}{[0.512]} \\
0.0045^{* * *}\end{array}$ & $\begin{array}{c}{[0.455]} \\
0.0047 * * *\end{array}$ \\
\hline $\begin{array}{l}\text { D.Reverse Repo } \\
\text { Rate } \times \text { Notice Era }\end{array}$ & $\begin{array}{c}{[0.573]} \\
1.09 * * *\end{array}$ & $\begin{array}{c}{[0.714]} \\
6.12^{* *}\end{array}$ & $\begin{array}{l}{[0.659]} \\
1.36 * *\end{array}$ & $\begin{array}{c}{[0.456]} \\
0.84 * * *\end{array}$ & $\begin{array}{c}{[0.730]} \\
0.51 * * *\end{array}$ & $\begin{array}{c}{[0.792]} \\
0.33 * * *\end{array}$ & $\begin{array}{c}{[0.557]} \\
0.38 * * *\end{array}$ & $\begin{array}{c}{[0.414]} \\
0.74 * * *\end{array}$ & $\begin{array}{c}{[0.011]} \\
0.27 * * *\end{array}$ & $\begin{array}{c}{[0.000]} \\
0.30 * * *\end{array}$ & $\begin{array}{l}{[0.000]} \\
0.20 * * *\end{array}$ & $\begin{array}{l}{[0.000]} \\
0.19 * * *\end{array}$ \\
\hline Constant & $\begin{array}{c}{[0.001]} \\
-0.0017 \\
{[0.860]}\end{array}$ & $\begin{array}{c}{[0.011]} \\
-0.0010 \\
{[0.913]}\end{array}$ & $\begin{array}{c}{[0.040]} \\
-0.0020 \\
{[0.678]}\end{array}$ & $\begin{array}{c}{[0.003]} \\
-0.00023 \\
{[0.981]}\end{array}$ & $\begin{array}{c}{[0.000]} \\
-0.0014 \\
{[0.895]}\end{array}$ & $\begin{array}{c}{[0.001]} \\
-0.0012 \\
{[0.888]}\end{array}$ & $\begin{array}{c}{[0.000]} \\
-0.0011 \\
{[0.895]}\end{array}$ & $\begin{array}{c}{[0.000]} \\
-0.0011 \\
{[0.861]}\end{array}$ & $\begin{array}{l}{[0.000]} \\
2.3 \mathrm{e}-06 \\
{[0.999]}\end{array}$ & $\begin{array}{c}{[0.000]} \\
-0.00023 \\
{[0.634]}\end{array}$ & $\begin{array}{c}{[0.000]} \\
-0.00049 \\
{[0.245]}\end{array}$ & $\begin{array}{c}{[0.000]} \\
-0.00061 \\
{[0.115]}\end{array}$ \\
\hline $\begin{array}{l}\text { R-squared } \\
\text { Quantile }\end{array}$ & $\begin{array}{l}0.000 \\
\text { OLS }\end{array}$ & $\begin{array}{c}0.004 \\
\text { OLS }\end{array}$ & $\begin{array}{c}0.003 \\
\text { OLS }\end{array}$ & $\begin{array}{c}0.001 \\
\text { OLS }\end{array}$ & $\begin{array}{l}0.000 \\
\text { OLS }\end{array}$ & $\begin{array}{l}0.000 \\
\text { OLS }\end{array}$ & $\begin{array}{c}0.001 \\
\text { OLS }\end{array}$ & $\begin{array}{c}0.001 \\
\text { OLS }\end{array}$ & $\begin{array}{c}0.003 \\
\text { OLS }\end{array}$ & $\begin{array}{c}0.019 \\
\text { OLS }\end{array}$ & $\begin{array}{c}0.023 \\
\text { OLS }\end{array}$ & $\begin{array}{c}0.029 \\
\text { OLS }\end{array}$ \\
\hline
\end{tabular}


Table 1.8. OMO Notice and Transmission Efficiency: Dynamic Results

\begin{tabular}{|c|c|c|c|c|c|c|c|c|c|c|c|c|c|c|c|c|c|c|c|c|c|c|c|c|}
\hline & (1) & (2) & (3) & (4) & (5) & (6) & (7) & (8) & (9) & (10) & (11) & $(12)$ & (13) & $(14)$ & $(15)$ & (16) & (17) & (18) & (19) & (20) & (21) & $(22)$ & (23) & (24) \\
\hline VARIABLES & $\begin{array}{c}\text { D.R0 } \\
01\end{array}$ & $\begin{array}{c}\text { D.R0 } \\
01\end{array}$ & $\begin{array}{c}\text { D.R0 } \\
07\end{array}$ & $\begin{array}{c}\text { D.R0 } \\
07\end{array}$ & $\begin{array}{c}\text { D.DR } \\
007\end{array}$ & $\begin{array}{c}\text { D.DR } \\
007\end{array}$ & $\begin{array}{c}\text { D.R0 } \\
14\end{array}$ & $\begin{array}{c}\text { D.R0 } \\
14\end{array}$ & $\begin{array}{l}\text { D.Shi } \\
\text { bor(1 } \\
\text { d) }\end{array}$ & $\begin{array}{l}\text { D.Shi } \\
\text { bor(1 } \\
\text { d) }\end{array}$ & $\begin{array}{l}\text { D.Shi } \\
\text { bor(1 } \\
\text { w) }\end{array}$ & $\begin{array}{l}\text { D.Shi } \\
\text { bor(1 } \\
\text { w) }\end{array}$ & $\begin{array}{l}\text { D.Shi } \\
\text { bor( } 2 \\
\text { w) }\end{array}$ & $\begin{array}{l}\text { D.Shi } \\
\text { bor( } 2 \\
\text { w) }\end{array}$ & $\begin{array}{l}\text { D.Shi } \\
\text { bor(1 } \\
\mathrm{m})\end{array}$ & $\begin{array}{l}\text { D.Shi } \\
\text { bor(1 } \\
\mathrm{m})\end{array}$ & $\begin{array}{l}\text { D.Shi } \\
\text { bor(3 } \\
\mathrm{m})\end{array}$ & $\begin{array}{l}\text { D.Shi } \\
\text { bor(3 } \\
\mathrm{m})\end{array}$ & $\begin{array}{l}\text { D.Shi } \\
\text { bor( } 6 \\
\mathrm{~m})\end{array}$ & $\begin{array}{l}\text { D.Shi } \\
\text { bor(6 } \\
\mathrm{m})\end{array}$ & $\begin{array}{l}\text { D.Shi } \\
\text { bor( }(9 \\
\mathrm{m})\end{array}$ & $\begin{array}{c}\text { D.Shi } \\
\text { bor( } 9 \\
\mathrm{~m})\end{array}$ & $\begin{array}{l}\text { D.Shi } \\
\text { bor(1 } \\
\text { y) }\end{array}$ & $\begin{array}{c}\text { D.Shi } \\
\text { bor(1 } \\
\text { y) }\end{array}$ \\
\hline Notice Era & No & Yes & No & Yes & No & Yes & No & Yes & No & Yes & No & Yes & No & Yes & No & Yes & No & Yes & No & Yes & No & Yes & No & Yes \\
\hline $\begin{array}{l}\text { D.Reverse } \\
\text { Repo Rate }\end{array}$ & $\begin{array}{c}- \\
0.058\end{array}$ & $\begin{array}{c}1.07 * \\
* *\end{array}$ & $\begin{array}{c}- \\
0.001 \\
6\end{array}$ & $\begin{array}{c}6.18^{*} \\
*\end{array}$ & 0.026 & $\begin{array}{c}1.37 * \\
*\end{array}$ & $\begin{array}{c}- \\
0.084\end{array}$ & $\begin{array}{c}0.83 * \\
* *\end{array}$ & $\begin{array}{c}- \\
0.038\end{array}$ & $\begin{array}{c}0.48^{*} \\
* *\end{array}$ & 0.031 & $\begin{array}{c}0.36^{*} \\
* *\end{array}$ & $-\overline{13} *$ & $\begin{array}{c}0.24 * \\
* *\end{array}$ & $\begin{array}{c}- \\
0.12 * \\
* *\end{array}$ & $\begin{array}{c}0.63^{*} \\
* *\end{array}$ & $\begin{array}{c}- \\
0.007 \\
2\end{array}$ & $\begin{array}{c}0.27 * \\
* *\end{array}$ & $\begin{array}{c}0.003 \\
6\end{array}$ & $\begin{array}{c}0.31 * \\
* *\end{array}$ & $\begin{array}{c}0.002 \\
0\end{array}$ & $\begin{array}{c}0.21 * \\
* *\end{array}$ & $\begin{array}{c}0.002 \\
2\end{array}$ & $\begin{array}{c}0.20^{*} \\
* *\end{array}$ \\
\hline $\begin{array}{l}\text { L. D. Reverse } \\
\text { Repo Rate }\end{array}$ & $\begin{array}{c}{[0.24} \\
5] \\
0.11\end{array}$ & $\begin{array}{c}{[0.00} \\
1] \\
1.13\end{array}$ & $\begin{array}{c}{[0.98} \\
4] \\
0.12\end{array}$ & $\begin{array}{c}{[0.01} \\
1] \\
- \\
2.10^{*} \\
* *\end{array}$ & $\begin{array}{c}{[0.73} \\
2] \\
0.024\end{array}$ & $\begin{array}{c}{[0.03} \\
9] \\
0.52\end{array}$ & $\begin{array}{c}{[0.29} \\
6] \\
0.12 * \\
*\end{array}$ & $\begin{array}{c}{[0.00} \\
5] \\
0.53\end{array}$ & $\begin{array}{c}{[0.19} \\
9] \\
0.12\end{array}$ & $\begin{array}{c}{[0.00} \\
0] \\
0.84\end{array}$ & $\begin{array}{c}{[0.74} \\
4] \\
0.088\end{array}$ & $\begin{array}{c}{[0.00} \\
0] \\
0.12\end{array}$ & $\begin{array}{c}{[0.06} \\
5] \\
0.11^{*} \\
*\end{array}$ & $\begin{array}{c}{[0.00} \\
0] \\
- \\
0.045\end{array}$ & $\begin{array}{c}{[0.00} \\
4] \\
- \\
0.33 * \\
*\end{array}$ & $\begin{array}{c}{[0.00} \\
0] \\
0.34^{*} \\
*\end{array}$ & $\begin{array}{c}{[0.56} \\
1] \\
- \\
0.005 \\
3\end{array}$ & $\begin{array}{c}{[0.00} \\
0] \\
0.15^{*} \\
* *\end{array}$ & $\begin{array}{c}{[0.30} \\
2] \\
0.001 \\
3\end{array}$ & $\begin{array}{c}{[0.00} \\
0] \\
0.24^{*} \\
* *\end{array}$ & $\begin{array}{c}{[0.50} \\
0] \\
- \\
0.000 \\
027\end{array}$ & $\begin{array}{c}{[0.00} \\
0] \\
0.26^{*} \\
* *\end{array}$ & $\begin{array}{c}{[0.45} \\
0] \\
0.000 \\
62\end{array}$ & $\begin{array}{c}{[0.00} \\
0] \\
0.23^{*} \\
* *\end{array}$ \\
\hline $\begin{array}{l}\text { L2. D. } \\
\text { Reverse Repo } \\
\text { Rate }\end{array}$ & $\begin{array}{c}{[0.18} \\
1] \\
- \\
0.17 * \\
*\end{array}$ & $\begin{array}{c}{[0.24} \\
0] \\
0.67 * \\
* *\end{array}$ & $\begin{array}{c}{[0.35} \\
1] \\
-0.16\end{array}$ & $\begin{array}{c}{[0.00} \\
0] \\
2.10^{*} \\
* *\end{array}$ & $\begin{array}{c}{[0.86} \\
0] \\
0.26^{*} \\
* *\end{array}$ & $\begin{array}{c}{[0.47} \\
1] \\
- \\
0.28^{*}\end{array}$ & $\begin{array}{c}{[0.03} \\
3] \\
0.026\end{array}$ & $\begin{array}{c}{[0.43} \\
6] \\
0.70^{*} \\
* *\end{array}$ & $\begin{array}{c}{[0.19} \\
1] \\
- \\
0.14^{*}\end{array}$ & $\begin{array}{c}{[0.15} \\
8] \\
0.074\end{array}$ & $\begin{array}{c}{[0.37} \\
1] \\
-0.24\end{array}$ & $\begin{array}{c}{[0.29} \\
8] \\
- \\
0.000 \\
19\end{array}$ & $\begin{array}{c}{[0.01} \\
2] \\
-0.12\end{array}$ & $\begin{array}{c}{[0.76} \\
3] \\
0.19^{*} \\
* *\end{array}$ & $\begin{array}{c}{[0.01} \\
3] \\
- \\
0.30 * \\
*\end{array}$ & $\begin{array}{c}{[0.01} \\
2] \\
0.32 * \\
*\end{array}$ & $\begin{array}{c}{[0.54} \\
0] \\
0.013\end{array}$ & $\begin{array}{c}{[0.00} \\
0] \\
0.16^{*} \\
* *\end{array}$ & $\begin{array}{c}{[0.43} \\
8] \\
0.005 \\
9\end{array}$ & $\begin{array}{c}{[0.00} \\
0] \\
0.12 * \\
* *\end{array}$ & $\begin{array}{c}{[0.98} \\
3] \\
0.004 \\
4\end{array}$ & $\begin{array}{c}{[0.00} \\
0] \\
0.21 * \\
* *\end{array}$ & $\begin{array}{c}{[0.52} \\
8] \\
0.002 \\
6\end{array}$ & $\begin{array}{c}{[0.00} \\
0] \\
0.18^{*} \\
* *\end{array}$ \\
\hline & $\begin{array}{c}{[0.04} \\
3]\end{array}$ & $\begin{array}{c}{[0.00} \\
0]\end{array}$ & $\begin{array}{c}{[0.46} \\
3]\end{array}$ & $\begin{array}{c}{[0.00} \\
4]\end{array}$ & $\begin{array}{c}{[0.00} \\
7]\end{array}$ & $\begin{array}{c}{[0.06} \\
1]\end{array}$ & $\begin{array}{c}{[0.87} \\
0]\end{array}$ & $\begin{array}{c}{[0.00} \\
8]\end{array}$ & $\begin{array}{c}{[0.06} \\
5]\end{array}$ & $\begin{array}{c}{[0.35} \\
0]\end{array}$ & $\begin{array}{c}{[0.10} \\
5]\end{array}$ & $\begin{array}{c}{[0.99} \\
9]\end{array}$ & $\begin{array}{c}{[0.26} \\
8]\end{array}$ & $\begin{array}{c}{[0.00} \\
4]\end{array}$ & $\begin{array}{c}{[0.03} \\
6]\end{array}$ & $\begin{array}{c}{[0.01} \\
8]\end{array}$ & $\begin{array}{c}{[0.23} \\
5]\end{array}$ & $\begin{array}{c}{[0.00} \\
0]\end{array}$ & $\begin{array}{c}{[0.26} \\
8]\end{array}$ & $\begin{array}{c}{[0.00} \\
0]\end{array}$ & $\begin{array}{c}{[0.39} \\
2]\end{array}$ & $\begin{array}{c}{[0.00} \\
5]\end{array}$ & $\begin{array}{c}{[0.26} \\
3]\end{array}$ & $\begin{array}{c}{[0.00} \\
3]\end{array}$ \\
\hline $\begin{array}{l}\text { L3.D. Reverse } \\
\text { Repo Rate }\end{array}$ & $\begin{array}{c}- \\
0.081\end{array}$ & 1.65 & -0.12 & 5.40 & $\begin{array}{l}0.12 * \\
*\end{array}$ & 0.67 & -0.33 & $\begin{array}{c}6.18^{*} \\
* *\end{array}$ & $\begin{array}{c}- \\
0.096\end{array}$ & $0.11 *$ & $\begin{array}{c}- \\
0.061\end{array}$ & 0.089 & -0.32 & $\begin{array}{l}0.20^{*} \\
*\end{array}$ & 0.079 & $\begin{array}{c}0.37 * \\
* *\end{array}$ & $\begin{array}{c}0.005 \\
5\end{array}$ & $0.32 *$ & $\begin{array}{c}0.001 \\
8\end{array}$ & $\begin{array}{c}0.12 * \\
* *\end{array}$ & $\begin{array}{c}- \\
0.001 \\
3\end{array}$ & $\begin{array}{c}0.16^{*} \\
* *\end{array}$ & $\begin{array}{c}- \\
0.000 \\
57\end{array}$ & $\begin{array}{c}0.14^{*} \\
* *\end{array}$ \\
\hline Constant & $\begin{array}{c}{[0.63} \\
3] \\
-\end{array}$ & $\begin{array}{c}{[0.18} \\
8] \\
0.001\end{array}$ & $\begin{array}{c}{[0.22} \\
2] \\
-\end{array}$ & $\begin{array}{c}{[0.12} \\
2] \\
0.001\end{array}$ & $\begin{array}{c}{[0.03} \\
5] \\
-\end{array}$ & $\begin{array}{c}{[0.25} \\
9] \\
0.000\end{array}$ & $\begin{array}{c}{[0.21} \\
6] \\
-\end{array}$ & $\begin{array}{c}{[0.00} \\
0] \\
0.008\end{array}$ & $\begin{array}{c}{[0.48} \\
1] \\
-\end{array}$ & $\begin{array}{c}{[0.08} \\
6] \\
0.001\end{array}$ & $\begin{array}{c}{[0.63} \\
3] \\
-\end{array}$ & $\begin{array}{c}{[0.18} \\
8] \\
0.000\end{array}$ & $\begin{array}{c}{[0.32} \\
0] \\
-\end{array}$ & $\begin{array}{c}{[0.02} \\
7] \\
0.003\end{array}$ & $\begin{array}{c}{[0.34} \\
2] \\
-\end{array}$ & $\begin{array}{c}{[0.00} \\
0] \\
0.003\end{array}$ & $\begin{array}{c}{[0.44} \\
9] \\
0.000\end{array}$ & $\begin{array}{c}{[0.06} \\
4] \\
0.003\end{array}$ & $\begin{array}{c}{[0.22} \\
1] \\
-\end{array}$ & $\begin{array}{c}{[0.00} \\
2] \\
0.003\end{array}$ & $\begin{array}{c}{[0.62} \\
1] \\
-\end{array}$ & $\begin{array}{c}{[0.00} \\
4] \\
0.003\end{array}$ & $\begin{array}{c}{[0.52} \\
5]\end{array}$ & $\begin{array}{c}{[0.01} \\
0] \\
0.003\end{array}$ \\
\hline & $\begin{array}{c}0.001 \\
8 \\
{[0.84} \\
9]\end{array}$ & $\begin{array}{c}{[0.84} \\
5]\end{array}$ & $\begin{array}{c}0.001 \\
2 \\
{[0.89} \\
9]\end{array}$ & $\begin{array}{c}{[0.93} \\
3]\end{array}$ & $\begin{array}{c}0.000 \\
64 \\
{[0.89} \\
5]\end{array}$ & $\begin{array}{c}47 \\
{[0.94} \\
1]\end{array}$ & $\begin{array}{c}0.000 \\
41 \\
{[0.96} \\
6]\end{array}$ & $\begin{array}{c}{[0.69} \\
0]\end{array}$ & $\begin{array}{c}0.001 \\
5 \\
{[0.88} \\
7]\end{array}$ & $\begin{array}{c}{[0.69} \\
6]\end{array}$ & $\begin{array}{c}0.001 \\
4 \\
{[0.86} \\
8]\end{array}$ & $\begin{array}{c}{[0.46} \\
6]\end{array}$ & $\begin{array}{c}0.001 \\
4 \\
{[0.86} \\
4]\end{array}$ & $\begin{array}{c}{[0.00} \\
0]\end{array}$ & $\begin{array}{c}0.001 \\
9 \\
{[0.76} \\
7]\end{array}$ & $\begin{array}{c}{[0.08} \\
5]\end{array}$ & $\begin{array}{c}{[0.99} \\
0]\end{array}$ & $\begin{array}{c}{[0.00} \\
1]\end{array}$ & $\begin{array}{c}0.000 \\
22 \\
{[0.64} \\
9]\end{array}$ & $\begin{array}{c}{[0.00} \\
0]\end{array}$ & $\begin{array}{c}0.000 \\
49 \\
{[0.24} \\
9]\end{array}$ & $\begin{array}{c}{[0.00} \\
0]\end{array}$ & $\begin{array}{c}0.000 \\
61 \\
{[0.11} \\
8]\end{array}$ & $\begin{array}{c}{[0.00} \\
0]\end{array}$ \\
\hline $\mathrm{R}$-squared & 0.001 & 0.031 & 0.001 & 0.050 & 0.008 & 0.020 & 0.003 & 0.042 & 0.001 & 0.033 & 0.002 & 0.030 & 0.004 & 0.063 & 0.010 & 0.075 & 0.000 & 0.069 & 0.000 & 0.140 & 0.000 & 0.330 & 0.000 & 0.256 \\
\hline
\end{tabular}

